\title{
THE NUTRITIVE VALUE OF ACID HYDROLYZED WOOD RESIDUE IN RUMINANT RATIONS
}

By

\author{
JACK WESSNER BUTTERBAUGH, JR。 \\ Bachelor of Science \\ Oklahoma State University \\ Stillwater, Oklahoma
}

1970

\author{
Submitted to the Faculty of the \\ Graduate College of the \\ oklahoma state University \\ in partial fulfillment of \\ the requirements for \\ the Degree of \\ MASTER OF SCIENCE \\ July, 1972
}


Thesis

1972

B988n

Cop: 2 
THE NUTRITIVE VALUE OF ACID HYDROLYZED

WOOD RESIDUE IN RUMINANT RATIONS

Thesis Approved:

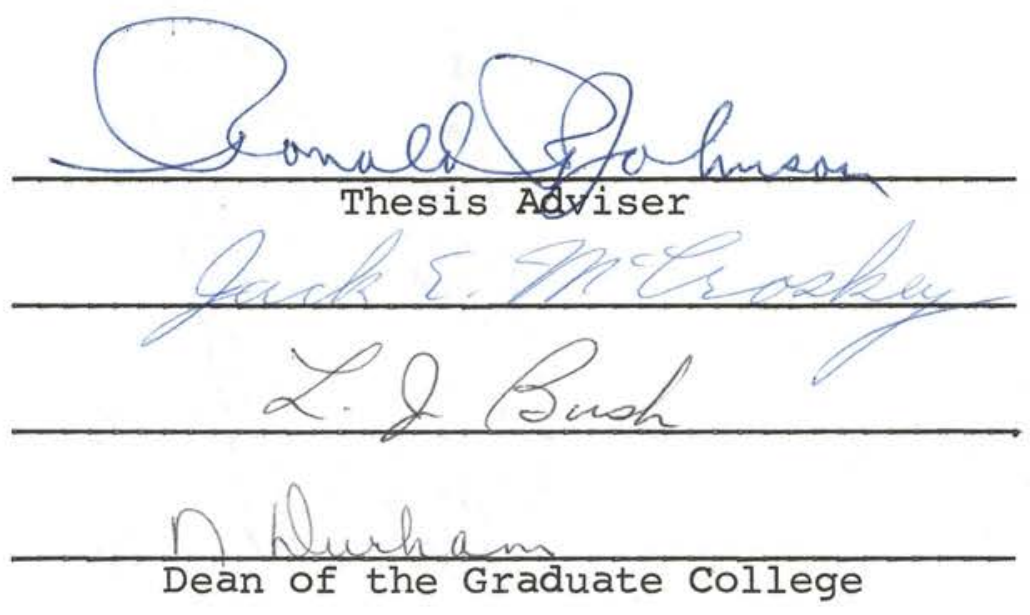

836785 


\section{ACKNOWLEDGMENTS}

The author wishes to express his appreciation to Dr. R.R. Johnson, Professor of Animal Science and Biochemistry, for his guidance and assistance during the course of this study. Appreciation is also extended to Dr. J.E. McCroskey and Dr. L.J. Bush for their help in the preparation of this manuscript.

Grateful acknowledgment is also extended to Dr. R.D. Morrison, Professor of Mathematics and statistics, for aid in conducting the statistical analysis of data.

Further acknowledgment is extended to fellow graduate students and Dr. H.E. Kiesling for their assistance and encouragement during the course of this study.

A very special thanks is given to the author's wife, Joy, for her most valuable help and understanding throughout this program of graduate study. 
TABLE OF CONTENTS

Chapter

Page

I. INTRODUCTION . . . . . . . . . . . . . . . 1

II. REVIEW OF LITERATURE. . . . . . . . . . . . 3

Introduction . . . . . . . . . . . 3

Sawdust in Ruminant Rations. . . . . . 3

Chemical Treatment of Wood Residue . . . 6

Alkaline Treatment of Wood Residue. - 6

Acid Treatment of Wood Residue. . . 10

Nylon Bag Technique. .. . . . . . . . . 13

III. MATERIALS AND METHODS . . . . . . . . 18

Introduction . . . . . . . . . . 18

Experimental Procedures. . . . . . . 20

Trial l. . . . . . . . . . . 20

Trial 2 . . . . . . . . . . . 22

Trial 3............... . 23

Trial 4......... . . . . . 25

Trial 5............... 26

Preparation of Samples and Chemical

Analysis........... . 26

Statistical Aralysis. . . . . . . 29

IV. RESULTS AND DISCUSSION. . . . . . . . . . . 31

Trial 1. . . . . . . . . . . 31

Trial 2.................. 43

Trial 3................. 45

Trial 4....... . . . . . . . . 57

Trial 5. . . . ............. 62

General Discussion . . . . . . . . 65

V. SUMMARY AND CONCLUSION. . . . . . . . . 69 SELECTED BIBLIOGRAPHY • • • - • • • • • • • • • 72 APPENDIX. . . . . . . . . . . . . . . . 78 


\section{LIST OF TABLES}

Table

Page

I. Composition of Experimental Rations Used in Trials 1 and 2 Dry Matter Basis . . . .

II. Composition of Experimental Rations Used in Trials 3 and 4 Dry Matter Basis. . . . . 24

III. Compostion of Experimental Rations Used in Trial 5 Dry Matter Basis. . . . . . .

IV. The Effect on Growth and Feed Efficiency of Adding Low Acid Hydrolyzed Wood Residue to Iamb Rations, With and Without soybean Meal Supplementation. . . . . . . . .

v. Digestion Coefficients of Rations Containing Low Acid Hydrolyzed Wood Residue. . . . .

VI. Digestion of Cellulose in Dacron Bags Suspended in the Rumen of Lambs Consuming Rations Containing Low Acid Hydrolyzed Wood Residue... . . . . . . . . .

VII. Rumen Fluid Volatile Fatty Acids for Trial 2.

VIII. The Effect on Growth and Feed Efficiency of Adding High Acid Hydrolyzed Wood Residue to Lamb Rations, With and Without sbybean Meal Supplementation. . . . . . . . .

IX. Digestion Coefficients of Rations Containing High Acid Hydrolyzed Wood Residue . . . . 54

X. Digestion of Cellulose in Dacron Bags Suspended in the Rumen of Lambs Consuming Rations Containifing High Acid "Hydrolyzed Wood Residue. . . . . . . . . . . .

XI Rumen Ammonia Nitrogen Concentration of Lambs Consumpuning HA-HWR in Trial $4 . . . .$.

XII. Rumen Volatile Fatty Acid Concentration of Lambs Consuming HA-HWR. .......... 
XIII. Total Moles of Volatile Fatty Acids Present at $0,1,2,4$ and 8 Hours Post-Feeding in the Rumen of Steers Consuming HA-HWR. . .

XIV. Grams of $\mathrm{NH}_{3}$ in the Rumen of steers Fed HA-HWR. . . . . . . . . . . . . . . .

XV. Sources of Variation and Degrees of Freedom Associated with the Analysis of Variance of Growth and Feed Efficiency Parameters Evaluated in Trial 1. . . . . . . . . .

XVI. Sources of Variation and Degrees of Freedom Associated With the Analysis of Variance of Digestibility Parameters Evaluated in Trial l. . . . . . . . . . . . .

XVII. Sources of Variation and Degrees of Freedom Associated With the Analysis of Variance of Dacron Bag and Volatile Fatty Acid Data Evaluated in Trial, 2. . . . . . .

XVIII. Sources of Variation and Degrees of Freedom Associated With the Analysis of Variance of Growth and Feed Efficiency Parameters Evaluated in Trial 3. . . . . . . . . . .

XIX. Sources of Variation and Degrees of Freedom Associated with the Analysis of Variance of Digestibility Parameters Evaluated in

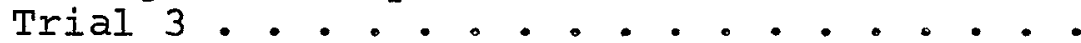

XX. Sources of Variation and Degrees of Freedom Associated With the Analysis of Variance of Dacron, Bag Rumen Ammonia, and Volatile Fatty Acid Data Evaluated in Trial 4. . .

XXI. Sources of variation and Degrees of Freedom Associated With the Analysis of Variance of Rumen Ammonia and Volatile Fatty Acid Data Evaluated in Trial 5. . . . . . . 


\section{LIST OF FIGURES}

Figure

Page

1. Body Weight Gain of Lambs Consuming LA-HWR With and Without SBM Supplement. . . . . . . . .

2. Dry Matter/kg of Gain Requirements of Lambs Consuming LA-HWR With and Without SBM Suppilement . • . • • • • • • • • • . • • • • • •

3. Non-wood Dry Matter/kg of Body Weight Gain of Lambs Consuming IAA-HWR With and Without SBM Supplement. . . . . . . . . . . . . .

4. Dry Matter Digestion Coefficients of Rations Containing LA-HWR . . . . . . . . . . . .

5. Percent Change in Cellulose Digestibility from Period 1 to Period 2 of Rations Containing LA-HWR. . . . . . . . . . • . . • • • .

6. Percent Change in Nitrogen Digestibility from Period 1 to Period 2 of Rations Containing LA-HWR. . . . . . . . . . . . . . . . .

7. Body Weight Gain of Lambs Consuming HA-HWR With and Without SBM Supplement. . . . . 50

8. Dry Matter $/ \mathrm{kg}$ of Gain Requirements of Lambs Consuming HA-HWR With and Without SBM Supplement. . . . . . . . . . . . . . .

9. Non-wood Dry Matter/kg of Body Weight Gain of Lambs Consuming HA-HWR W'ith and Without SBM Supplement. • • • • • • • • • • • • 52

10. Dry Matter Digestion Coefficients of Rations

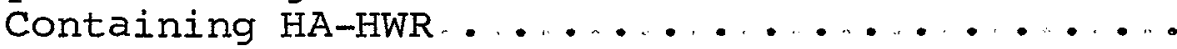

11. Percent Change in Cellulose Digestibility From Period 1 to Period 2 of Rations Containing HA-HWR . . . . . . . . . . . 


\section{CHAPTER I}

\section{INTRODUCTION}

Through the years wood has evoked little interest in the diet of ruminants; only in times of national emergencies has any great quantity of wood or wood residue been fed to ruminants. The concept of feeding wood is very old, but until recently the practice has received little attention from researchers in developing the use of wood or wood by-products as an energy source for ruminants. Several factors have increased the interest in the utilization of wood. It is evident that the domestic animal will eventually compete with the human for cereal grain and other foodstuffs that are being produced for use by man; therefore, animals will be forced to utilize food supplies that cannot be utilized by humans. With increased pressure to dispose of refuse from harvesting and milling practices in a manner that does not add increased pollution to our environment, the wood industry is in search of products that could utilize great quantities of low quality wood or wood residues.

Researchers have studied the incorporation of raw sawdust into ruminant rations but have been unable to incorporate more than minor quantities without depression 
of intake and gain. Other workers have studied the use of chemical treatment of wood and poor quality forages by treating with alkaline reagents to release cellulose from the lignin-cellulose complex. Very little attention has been given to the use of acid hydrolyzed wood residue as an energy source for ruminants.

The purpose of this study was to compare the nutritive value of rations containing acid hydrolyzed wood residue to alfalfa meal diets. The methods used consisted of feeding trials, digestion trials and studies on in vivo volatile fatty acid concentrations. Data on digestion of cellulose in dacron bags suspended in the rumen were collected to determine if the level of hydrolyzed wood in the diet influenced the ability of rumen microorganisms to digest cellulose. 
CHAPTER II

\title{
REVIEW OF LITERATURE
}

\section{Introduction}

\begin{abstract}
Although wood contains a relatively high amount of carbohydrates, $70-80 \%$, most of it is indigestible by the ruminant animal. Research workers have considered the problem from two viewpoints. Wood can be considered an inert ingredient that can be incorporated into ruminant rations in small amounts to serve as a roughage factor. The other view is that by chemically treating wood to improve its digestibility it may be considered a potential energy source for the ruminant animal. This review will cover the use of chemically treated and untreated wood in ruminant rations and the use of the dacron bag technique as a method for evaluating feedstuffs.
\end{abstract}

\section{Sawdust in Ruminant Rations}

The utilization of untreated wood residue has been tried by several researchers. Most have found untreated wood to be nearly indigestible by the ruminant animal. The degree of digestibility of wood has been shown to be very species dependent. Millet et al. (1970) using in 
vitro methods tested 24 species of wood and found that only three species were digested to any extent by rumen microorganisms (aspen $32 \%$, black ash $17 \%$, soft maple $30 \%$, and all other species $0-8 \%$ ) Similar results have been obtained by Fiest, Baker and Tarkow (1970) .

Satter, Baker and Millet (1970) have shown that aspen sawdust can replace $30 \%$ of a conventional ration in dairy cattle producing $20 \mathrm{~kg}$ of milk daily without reducing the intake of digestible dry matter or the production of milk. Cows consuming the aspen sawdust maintained a normal milk fat level. Mellenberger et al. (1970) obtained digestion coefficients of $41 \%$ when aspen was incorporated into a high-roughage ration and $28 \%$ when in a high-concentrate ration fed in the diets of goats.

In contrast to the data supporting the use of untreated aspen, Dinius et al. (1970) has confirmed that oak is essentially indigestible by sheep, thus making it a poor energy source. Researchers working with the utilization of indigestible woods have used them primarily as roughages or diluents in high concentrate rations with fair success.

Anthony and Cunningham (1969) reported that a ration containing $2.5 \%$ hardwood sawdust supported, a higher rate of gain than a basal ration or a basal ration plus $10 \%$ sawdust. In further work with oak sawdust it was found that sawdust included at $10 \%$ of the ration gave equal performance to rations containing an equal amount of coastal 
bermudagrass; however, cattle fed $15 \%$ sawdust showed depressed gains and consumed slightly less feed than the coastal bermudagrass fed cattle. This led Anthony and Cunningham (1969) to conclude that sawdust could be added to steer rations up to a level of $10 \%$ with favorable results. Kitts et al. (1969) conducted several trials with alder sawdust and found similar results. Steers fed grass hay gained faster and had better feed efficiency than those fed untreated sawdust at 15 and $20 \%$ of the rations. el-Sabban, Long and Baumgardt (1971) compared oak sawdust fed at $5 \%$ and $15 \%$ of the diet with oyster shells and ground timothy hay as roughages in cattle rations. Feedlot performance data indicated that sawdust could be used successfully at levels up to $15 \%$ of the ration without significantly effecting performance. Coarse ground sawdust gave better results than fine ground sawdust.

At stages in the life cycle of ruminants it may be advantageous to limit energy intake to prevent rapid growth or unwanted fattening. Dinius and Baumgardt (1970) used oak sawdust in the ration. Dilutions up to $35 \%$ allowed regulation of energy intake. Cody, Morill, and Hibbs (1968) reported that grain intake can be controlled by including $25-45 \%$ wood fiber with grain in rations of dairy animals. Although it has been shown that limited quantities of wood or sawdust may be used as a roughage factor or a diluent in ruminant rations, it is evident that most 
species of wood fed without chemical or physical treatment are unsatisfactory as major components in the ruminant diet. This has caused increased interest in the alteration of wood to make it more digestible by the ruminants.

\section{Chemical Treatment of Wood Residue}

Before wood residue can receive any appreciable consideration as an energy source for ruminants some form of pretreatment is necessary to release wood carbohydrates. As stated by Guggolz, Kohler and Klopfenstein (1971)。 carbohydrate availability is related to one or more of three factors, (1) lignin acts as an inert barrier between the carbohydrate and the digesting enzyme, (2) the cellulose is too highly crystalline to be quickly available to enzyme action or (3) silica inhibits carbohydrate digestibility.

Research has concentrated on the removal of lignin and solubilization of some hemicellulose by treating with alkaline reagents, or on acid hydrolysis as a means of degrading wood carbohydrate to sugars without the removal of lignin. Because of the expense associated with conventional pulping methods they have not been extensively investigated although they ultimately remove Iignin and yield cellulose in a usuable form.

\section{Alkaline Treatment of Wood Residue}

The treatment of fibrous materials by dilute alkaline 
reagents has been investigated by several researchers. The original process of $\mathrm{NaOH}$ treatment of roughages was patented by Beckman in 1918. The procedure was a modification of earlier practices which required heat in the digesting process. The Beckman process involved hydrolysis of forages with eight times its weight of 1.5 percent $\mathrm{NaOH}$ in open vats for approximately 3 hours. The liquor was then drained off and the remaining fiber was washed until neutral. Although this process increased the yield of digestible fibrous material, a considerable loss in soluble nutrients was apparent. Much of the early work was conducted in Germany and was reviewed by Archibald (1924). An early explanation for the action of alkaline reagents is that given by Magnus in his "Theorie and Praxis der strogayfshliessung" (30, p. 7-13) as cited by Archibald (1924).

Separation and solution of the silicic acid, which constitutes a portion of the incrusting substance of the straw and is present in most straws to the extent of 1 to 2 percent, while some straws contain as much as 5 percent.

Splitting off of the methoxy and acetyl groups from the lignin, of which they form a characteristic part. This results in the production of acetic acid with consequent neutralization of more or less of the alkali employed in the process. The lignin itself is also profoundly changed and is rendered more insoluble and inactive. It should be borne in mind, however, that complete, or nearly complete, solution and removal of the lignin can be brought about when desired by repeated treatment with alkali at higher temperatures than those successfully employed for straw hydrolysis. In paper manufacture this is what actually takes place. 
Forcing or springing of the bonds which link the lignin and cellulose together. The theory of a linkage between these two substances in the fiber is advanced by Magnus, and he considers that the springing apart of these bonds is the most important and essential nature in the action of the alkali. As a result, the intestinal bacteria of animals are enabled to attack the cellulose and split it up into simpler substances, such as sugars and organic acids which can then be utilized by the animal organisms.

Holtzer (1952) reported that alkaline degradation appears to involve three separate stages. (1) The absorption of alkali at the lignin interface by acidic phenolic groups in the lignin complex. This process is rapid and does not influence the reaction rate. Following absorption of alkali, a chemical combination takes place between lignin and the absorbed alkali. In the final stage, chemical hydrolysis takes place and the alkali-lignin surface enters the liquid. The energy calculated to be necessary for the solution of one alkalilignin complex is in the order of $5.3 \times 10^{-23}$ calories. Tarkow and Fiest (1969) recently suggested that dilute alkali treatment of wood increased the digestibility of wood by sponifying ester bonds on xylan chains acting as cross links that restrain swelling. They also reported the saponification of acetyl groups in wood. From this they theorized that knowing the amount of esterified and nonesterified uronic acid groups and acetyl groups in the wood, it is possible to calculate the $\mathrm{NaOH}$ requirement for saponification and therefore for maximum improvement in 
digestibility. The increase in digestibility is due to the increased accessibility of the wood to hydrolytic attack by celluloytic organisms. Using their theoretical model and data on the chemical composition of oak and aspen, they calculated that it would require 5.1 grams of $\mathrm{NaOH}$ per 100 grams of wood for aspen and 4.5 grams of $\mathrm{NaOH}$ per 100 grams for oak. In vitro digestion trials indicated 5 to 6 grams of $\mathrm{NaOH}$ per 100 grams of wood were required to obtain maximum digestibility, and the minimum ratio for the maximum digestibility was independent of species. The maximum digestibility of aspen was about $50 \%$, and the maximum with red oak was about $15 \%$.

The problem of nutrient loss by solubilization may approach $25 \%$ by leaching during the washing operation as shown by Singh and Jackson (1971) and Saxena et al. (1971). Cost of processing and loss of nutrients are major reasons for only minor use of the technique. Recently Wilson and Pigden (1964) described a process for treatment of forages and wood that did not involve leaching after treatment with NaOH. The dry roughage was sprayed with 0 to $10 \%$ sodium hydroxide. It was then neutralized by exposing to atmospheric $\mathrm{CO}_{2}$ or by mixing it with silages or acetic acid. Working with poplar wood they showed that the in vitro digestibility could be increased from 5 to approximately 40\%。 Other workers (Maeng, Mowat and Bilanski, 1971, Guggolz et al., 1971, Saxena et al., 1971, and Singh et al.。 1971) have shown similar results with straw and low 
quality forages.

Mellenberger et al. (1971) used alkali concentration only slightly greater than the amount needed for saponification of acetyl and carboxyl groups. The fiber was than washed once with a resulting weight loss of $5 \%$. The in vitro dry matter digestibility was increased from $41 \%$ to $52 \%$ using aspen wood as the test material.

Many modications are used in the treatment of forages and wood fibers with alkaline reagents. The effectiveness of treating with alkali to improve digestibility is closely related to the species of wood or forage being used as suggested by Tarkow aud Feist

\section{Acid Treatment of Wood Residue}

The acid hydrolysis of wood is used in the production of wood alcohol and wood molasses. Limited research has been conducted on the adaptation of the process to the production of animal feeds. Acid hydrolysis of wood involves the interaction of water with the various components of wood. At ordinary temperature and pressure, the reaction with water is so slow that it is not detected by usual analytical procedures. The action may be catalyzed by heat, acids or pressure so that the reactions occur more rapidly. (Harris, 1952)

Hydrolysis of the components of wood require varying conditions. Conditions which hydrolyzed hemicellulose and the lignin to soluble products leave the cellulose un- 
changed. The resistance of cellulose to hydrolysis is assumed to be due to the crystalline nature of cellulose rather than the type of linkage between the glucose molecules. Cellulose requires temperature corresponding to 150 psi steam pressure with 0.8 percent sulfuric acid for 20 to 30 minutes to convert half of the cellulose into simple sugars. (Harris, 1952)

Early work in the development of dilute acid hydrolysis of wood into an animal feed was conducted by Sherrard and $\mathrm{Bl}$ anco (1921). Their procedure treated sawdust in the same manner as for the production of ethyl alcohol. Sawdust was digested with 0.8 percent sulfuric acid for 15 or 20 minutes under 120 pounds of steam pressure. The acid and soluble sugars were extracted and neutralized with lime. The sugars were then evaporated and combined with the residue remaining after hydrolysis. Analysis revealed that the finished product yield was 90 to $94 \%$ of the original wood. Loss in weight was largely accounted for by the conversion of the pentosans of the hemicellulose fraction to furfural and volatile acids. The original wood was found to be $56 \%$ cellulose. The cellulose remaining after hydrolysis calculated upon the weight of the original wood was 34 percent. This indicated that approximately 40 percent of the cellulose was hydrolyzed. From this a yield of $15 \%$ total reducing sugar was produced (based on weight of original wood). It is of interest to note that the total quantity of lignin contained in the wood (31\%) was 
not altered by this method of acid hydrolysis.

Feeding trials were conducted by several investigators using the hydrolyzed wood produced by sherrard and Blanco (1921). Archibald (1926) conducted digestibility trials to evaluate the feeding value of hydrolyzed Douglas fir sawdust, Eastern white pine and the residue of Eastern white pine minus the liquor produced. The residue was fed to evaluate the assumption that it was probably without food value. Results of the digestion trials revealed that hydrolyzed Douglas fir sawdust was about 33\% digestible. Dry matter of hydrolyzed Eastern white pine (residue and liquor) was found to be $46 \%$ digestible. Archibald noted that the residue from the Eastern white pine when fed to lambs caused digestive disturbances and yielded dry matter digestion coefficient of $18 \%$. (Average of four trials varying from 1.69 to $32.41 \%$ )

The most promising approach to the utilization of acid hydrolyzed wood residue is the hydrolysis of the polysaccharides to soluble sugars and the preparation for use in the form of molasses. Improvements in hydrolysis and evaporating equipment have made it possible to evaporate low yield sugar solutions to molasses. Several workers have found wood molasses to be comparable to cane molasses in feeding value as stated by Jones (1949). Harris (1952) reported the hydrolysis of hardwood, such as aspen, would yield about 1 ton of 50\% sugar solution per ton of wood. These processes are limited by economics and the 
use of the remaining residue after hydrolysis.

The problem of using the residue for an animal feed is compounded by methods of hydrolysis. The formation of carbohydrate decomposition products during the hydrolysis of wood may increase the indigestible residue which may be detected as a resinous humic material with lignin-like properties. Furfural, the decomposition product of xylose, may be produced at the extent of 2 to 3 percent of the weight of the wood. In the presence of dilute mineral acids at elevated temperature, hexose sugars undergo decomposition, producing among other substances hydroxymethylfurfural and eventually levulinic acid. Many of these products are not metabolizable or are toxic to microorganisms.

\section{Nylon Bag Technique}

Research workers have investigated methods for obtaining an estimate of forage nutritive value by the use of small sample methods. The majority of these procedures are based on the use of in vitro techniques; however, work has been conducted on the use of small sample in vivo techniques by the use of cotton threads, dialysis membrane bags, and nylon or dacron bags suspended in the rumen of the test animal.

Hoflund, Quin and Clark (1948) used cotton threads to study the rate of cellulose digestion when placed in the rumen of fistulated sheep. Balch and Johnson (1950) used cotton threads to determine that cellulose is broken 
down faster in the ventral sac of the rumen than in the dorsal sac.

Pettyjohn, Leatherwood and Mochrie (1964) used a dialysis membrane bag inside a plastic cylinder to simulate rumen conditions. The nature of the bag prevents entrance of nondialyzable molecules or particles, and allows diffusion of end products such as volatile fatty acids without escape of small feed particles. This procedure has several disadvantages in that the membrane bag will deteriorate after extended periods of time in the rumen. The dialysis membrane bag method requires an in vitro type preparation as the digesting media, including inoculum since the microorganisms of the rumen from the test animal cannot penetrate the membrane.

The most widely used methods for small sample in vivo evaluation of forages are based on the use of the weighted nylon or dacron bag suspended in the rumen of a fistulated sheep. The pores in the nylon allow movement of rumen liquor in and out of the bag without allowing escape of undigested particles of the feed or forage being evaluated. Several workers have investigated the use of the nylon bag technique as a means of relating estimates of digestion coefficients to coefficients obtained by conventional digestion trials. Quin, Van der Wath and Mybrugh (1938) observed disintegration of feed samples by suspending small hylon bags in the rumen of fistulated sheep. Van Keuren and Heineman (1962) evaluated the nylon bag technique and were able 
to obtain good repeatability between samples taken over a series of days. Anthony et al. (1969) used the nylon bag technique to determine dry matter digestibility of rations containing 10 and $15 \%$ sawdust. His data were corrected by using forages of known digestibility placed in the rumen with the test ration.

One major problem encountered by researchers using dry matter digestibility in the nylon bag was the effect of washing time on the dry matter disappearance. Van Dyne (1962) reported that rinsing of nylon bags upon removal from the animal as compared to thorough repeated washing and soaking resulted in large (highly significant) differences in estimates of dry matter digestion. Other workers have also found washing time to be a factor effecting dry matter digestibility coefficients obtained by the nylon bag technique (Manta, 1969)。

Cellulose digestion in small nylon bags as an estimate of actual cellulose digestion has been used successfully by Lusk, Browning and Miles (1962). They found that a correlation coefficient of $+0.83(\mathrm{P}<.05)$ was obtained when the 48 hour legume and 72 hour grass hay nylon bag digestion coefficients were compared with results from conventional digestion trials. Significant positive correlations between cellulose digestion measured by two methods indicated that the nylon bag technique used with a regression equation might provide a valid estimate of cellulose digestion in nylon bags were small although significant. 
Van Dyne (1962), evaluating factors influencing digestion coefficients obtained by the nylon bag technique, found that sample size was inversely related to in vivo cellulose digestion in the range of sample sizes from 2 to 10 grams of ground forage. Length of fermentation period appeared to have a linear relationship to cellulose digestion between 24 and 72 hours when annual range forage was evaluated. Van Keuren et al. (1962), Neathery (1969), and Erwin and Ellistan (1959) have reported dry matter digestion coefficients obtained by the nylon bag technique were decreased by increasing sample size (from 2 to 24 grams) and directly influenced by length of the time in the rumen.

The dietary regime of the test animal has been shown to be a major source of variation in estimating digestion coefficients with the nylon bag as demonstrated by Neathery (1969), Van Keuren et al. (1962), and Van Dyne (1962). Hopson, Johnson and Dehority (1963) reported the dietary regime of the test animal had a significant effect on the digestion coefficients obtained from the nylon bag technique. It was also noted that the nylon bag technique is not well adapted to the estimation of in vivo digestion coefficients when using incubation times less than 42 hours.

Due to the sources of variation associated with the nylon bag technique, Johnson (1966) suggested the nylon bag technique would find better application in determining 
the effects of various ration treatments on the rate of digestion within the rumen than in determining estimated digestion coefficients.

The use of the nylon bag to demonstrate inhibition of cellulose digestion was used by el-Shazly, Dehority and Johnson (1961) by placing shredded filter paper in nylon bags and determining cellulose disappearance when the corn level in hay and corn diets were changed. Lambert and Jacobson (1958) used nylon bags containing cellulose to measure the inhibition of cellulose digestion caused by chlorotetracycline in rations fed to cattle. 


\section{CHAPTER III}

\section{MATERIALS AND METHODS}

\section{Introduction}

Five trials were conducted to evaluate the nutritive value of acid hydrolyzed wood residue. Two degrees of dilute sulfuric acid hydrolysis were evaluated. Low acid hydrolyzed wood residue (IA-HWR) was produced by treating the wood material with $0.8 \% \mathrm{H}_{2} \mathrm{SO}_{4}$ (dry wood basis) for 60 seconds at $4.2185 \times 10^{4} \mathrm{~g} / \mathrm{cm}^{2}$ pressure. High acid hydrolyzed wood residue (HA-HWR) was produced by treating the wood material with $2.3 \% \mathrm{H}_{2} \mathrm{SO}_{4}$ (dry wood basis) for 40 seconds at $4.2185 \times 10^{4} \mathrm{~g} / \mathrm{cm}^{2}$ pressure. No products of the acid hydrolysis were removed during the processing of the wood residue. After hydrolysis both treatments were neutralized with anhydrous ammonia to a pH of approximately 6.5. The addition of ammonia gave the resulting product a crude protein value of $15 \%$. The dry matter contents of the LA-HWR and HA-HWR were $60 \%$ and $50 \%$, respectively. The wood residue used in both acid treatments consisted approximately of $80 \%$ hardwood and $20 \%$ pine material.

Trial 1 was a growth, feed efficiency, and digestibility trial in which give rations containing LA-HWR 
were fed to evaluate the performance of growing lambs fed high levels of hydrolyzed wood residue. These rations were compared to a basal control ration composed of alfalfa meal. Rations containing 25, 50, and 75\% LA-HWR were balanced with soybean meal to be isonitrogenous with the alfalfa meal. Two rations containing 50 and $75 \%$ LA-HWR were formulated with no additional nitrogen supplement.

Trial 2 was used to determine if the level of LA-HWR used in the diet influenced the ability of rumen microorganisms to digest cellulose. The six rations used in trial 1 were used in this study. Dacron bags (suspended in the rumen) containing soybean hulls were used to detect differences in cellulose digestion caused by the treatments applied. Differences in rumen volatile fatty acid (VFA) concentrations were also measured.

Trial 3 was a growth, feed efficiency and digestibility trial, similar to trial 1, using HA-HWR. Due to severe depression in palability caused by the high acid bydrolyzed wood residue, HA-HWR was incorporated into the basal diet at 20 and $35 \%$ with added soybean meal and at 20 and $35 \%$ with no additional nitrogen supplement. A basal control ration of alfalfa meal was also fed in this trial.

Trial 4 was designed to study differences in the cellulose digestion using the dacron bag technique when HA-HWR was incorporated into the diet at 0,25 , and 35\%. Ruminal ammonia-nitrogen and volatile fatty acid concentrations 
were also measured.

Trial 5. was used to evaluate the total concentration of volatile fatty acids and ammonia-nitrogen present in the rumen of steers consuming rations containing 25 and $50 \%$ HA-HWR as compared to an alfalfa meal diet.

\section{Experimental Procedure}

\section{Trial I}

Thirty-four wether lambs (Hampshire $\mathrm{x}$ Western and Dorset) weighing approximately $20 \mathrm{~kg}$ were randomly placed in individual pens (140 cms $x 84 \mathrm{cms}$ ) with slotted floors. The lambs were maintained on a high roughage ration until allotment to treatment.

Feed and water were withheld for 16 hours prior to taking the intitial weight of the lambs. On the basis of the initial weight, the lambs were divided into three weight groups (heavy, medium and light). The lambs were then randomly allotted to 6 ration treatments (Table I). Two lambs from each weight group were allotted to each ration treatment ( 6 lambs per treatment) with the exception of rations 1 and 5 which were allotted 5 lambs per treatment.

The lambs were allowed to eat ad libitum. Refused feed was weighed and recorded to determine daily feed consumption. Free access to water was allowed at all times. After 89 days on their assigned treatments the lambs were 
TABLE I

COMPOSITION OF EXPERIMENTAL RATIONS USED IN TRIALS 1 AND 2 DRY MATTER BASIS

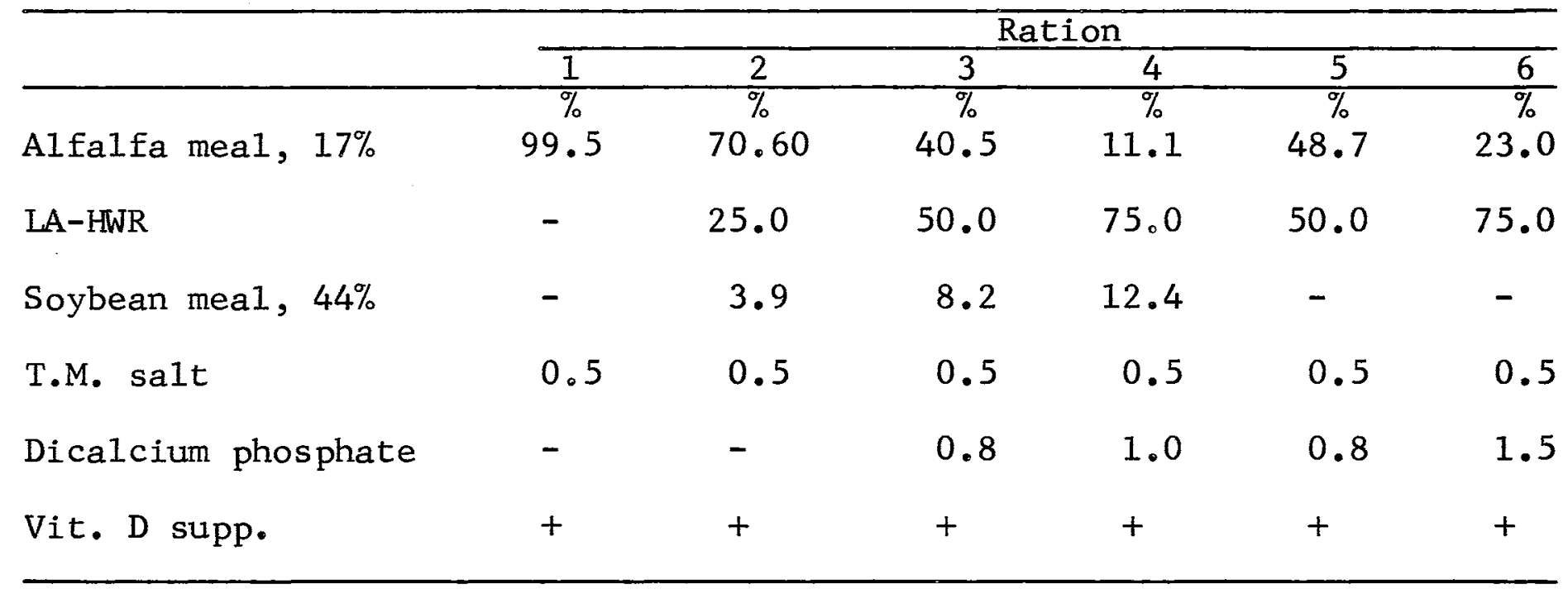


withheld from feed and water for 16 hours and weighed.

The effects of the treatment imposed were measured by weight gain and feed efficiency data. In addition, the amount of non-wood dry matter per $\mathrm{kg}$ of gain was calculated to determine if LA-HWR was replacing any of the basal feed required to support gain.

All lambs were used concurrently in a digestion study. The thirtylfour lambs were fitted with canvas collection bags and total collections of feces were made over seven day periods starting on days 14 and 49 of the feeding period.

All feed used in trials 1 and 2 , and all subsequent trials were mixed in $100 \mathrm{~kg}$ batches. Feed and feces samples were chemically analyzed for dry matter, organic matter, cellulose, and nitrogen. Digestion coefficients of the rations were calculated for the respective fractions. Digestion coefficients of the LA-HWR were calculated by regression of the ration digestion coefficients.

Trial 2

Twelve lambs fitted with permanent rumen cannulas were randomly allotted to the 6 LA-HWR treatments used in trial 1 (Table I) using two lambs per treatment. All lambs were kept in individual pens and allowed to eat ad libitum with free access to water.

Dacron bags, similar to those used by Hopson (1963), measuring $5 \mathrm{cms} \times 10 \mathrm{cms}$ were constructed from lining 
material with a thread count of 40 × 50 threads per $\mathrm{cm}^{2}$. The bags were then tied securely with $38 \mathrm{~cm}$ lengths of nylon cord, which were used to attach them to the cannula. On days 14, 35, and 56, six dacron bags, each containing 1 gram of soybean hulls, were placed in the rumen of each lamb via the rumen cânnula, 4 hours post feeding. Two bags were removed from each lamb at 15, 30 and 48 hours after being placed in the rumen.

After the nylon bags were removed from the rumen, they were washed of adhering rumen contents and frozen for later analysis for cellulose.

Samples of rumen contents were taken before feeding and at 1, 2 and 4 hours post feeding on days 39 and 60 . Rumen ingesta was obtained by opening the rumen cannula and allowing approximately $300 \mathrm{ml}$ to flow freely into a flask.

$\underline{\text { Trial } 3}$

Thirty wether lambs (Dorset $\mathrm{x}$ Rambouillet) weighing approximately $24 \mathrm{~kg}$ were allotted to pens similar to those used in trial 1. After the initial weighing and allotment to three weight groups (heavy, medium and light), two lambs from each group were randomly allotted to 5 treatments (Table II) with rations containing high acid hydrolyzed wood residue (HA-HWR).

The lambs were maintained on their assigned treatment for 90 days and were then withheld from feed and water for 
TABLE II

COMPOSITION OF EXPERIMENTAL RATIONS USED IN TRIALS 3 AND 4 DRY MATTER BASIS

\begin{tabular}{|c|c|c|c|c|c|}
\hline & & & Rati & & \\
\hline & 1 & 2 & 3 & 4 & 5 \\
\hline Alfalfa meal & $\begin{array}{c}\% \\
99.5\end{array}$ & $\begin{array}{c}\% \\
72.85\end{array}$ & $\begin{array}{c}\% \\
52.79\end{array}$ & $\begin{array}{c}\% \\
79.50\end{array}$ & $\begin{array}{c}\% \\
64.00\end{array}$ \\
\hline HA-HWR & - & 20.00 & 35.00 & 20.00 & 35.00 \\
\hline Soybean meal & - & 6.24 & 11.51 & - & - \\
\hline T.M. salt & 0.5 & 0.5 & 0.5 & 0.5 & 0.5 \\
\hline Dicalcium phosphate & - & - & 0.2 & - & 0.5 \\
\hline Vit. D supp., gm/100 Ib. & 0.5 & 0.5 & 0.5 & 0.5 & 0.5 \\
\hline
\end{tabular}


16 hours and weighed.

The parameters used to evaluate growth and efficiency of feed utilization were total weight gain, average daily gain and dry matter per $\mathrm{kg}$ of gain. Non-wood dry matter per $\mathrm{kg}$ of gain was calculated to determine the amount of basal feed replaced by feeding different levels of HA-HWR. A digestion trial similar to that conducted in trial 1 was conducted concurrently with the thirty lambs in trial 3, starting on day 14 and day 49 of the growth trial. $\underline{\text { Trial } 4}$

Twelve lambs (of similar weight and breeding as those used in trial 3) fitted with permanent rumen cannulae were randomly allotted to treatments 1,2 and 3 (Table II) of the treatments used in trial 3 with HA-HWR. Four lambs were allotted per treatment and randomly allotted to individual pens.

Dacron bags similar to those used in trial 2 with LA-HWR were filled with 1 gram of soybean hulls. Six bags were tied to a weighted and sealed $12 \mathrm{~cm}$ length of tygon tubing. A $38 \mathrm{~cm}$ length of nylon cord was attached to one end of the tubing and connected to the cannula. On days 14,35 and 56 the weighted bars and six attached bags were placed in the rumen of each lamb via the rumen cannula at 4 hours post feeding. As in trial 2, two bags each were removed at 15, 30 and 48 hours after being placed in the rumen and were washed and frozen as described 
for trial 2 .

Rumen content samples were taken before feeding and at $1,2,4$ and 8 hours post-feeding on days 18, 39 and 60 for VFA and rumen ammonia analysis.

Trial 5

Three mature hereford steers fitted with rumen cannulas were used in a $3 \times 3$ latin square design using rations containing 0,25 and 50\% HA-HWR (Table III). A 21 day adaptation period was allowed between each ration change. On days 21 and 25 of each period, rumen liquor samples were taken before feeding and at 1, 2, 4 and 8 hours post-feeding. Fifty grams of polyethylene glycol (PEG), M.W. 4,000, dissolved in $100 \mathrm{ml}$ of water was administered via the rumen cannula after the first rumen fluid sample was taken each day. Rumen fluid samples were analyzed for VFA concentration, rumen ammonia-nitrogen and PEG. PEG was used to measure rumen volume by regressing the values obtained to zero time. By calculating the rumen volume the total concentrations of VFA and ammonia were obtained for each steer on each ration.

\section{Preparation of Samples and Chemical Analysis}

Feces collected during the digestion trials were weighed daily and $10 \%$ aliquots were composited and stored at $-4^{\circ} \mathrm{C}$. until analyzed. Wet fecal samples were used for nitrogen analysis. Eighty grams of wet feces were 
TABLE III

COMPOSITION OF EXPERIMENTAL

RATIONS USED IN TRIAL 5

DRY MATTER BASIS

\begin{tabular}{lccc}
\hline & \multicolumn{3}{c}{ Ration } \\
\cline { 2 - 4 } & $\frac{2}{2}$ & $\frac{3}{\%}$ \\
Alfalfa meal & 99.5 & 74.5 & 49.0 \\
HA-HWR & 0.0 & 25.0 & 50.0 \\
T.M. salt & 0.5 & 0.5 & 0.5 \\
Dicalcium phosphate & 0.0 & 0.0 & 0.0 \\
\hline
\end{tabular}


mixed with $400 \mathrm{ml}$ of distilled water in a Waring blender. An aliquot of this was analyzed for nitrogen by the Kjeldahl procedure. The remaining fecal, sample was than dried at $60^{\circ} \mathrm{C}$. in a forced air oven for 24 hours, allowed to equilbrate to atmospheric conditions for 24 hours, then ground through a $1 \mathrm{~mm}$ screen in a Wiley mill. The air dried samples were stored in sealed containers. Final dry matter and ash were determined by standard A.O.A.C. (1960) methods. Cellulose was determined by procedures described by Crampton and Maynard (1938).

Soybean hulls ( $49.10 \%$ cellulose) were used as a source of cellulose in the dacron bags because they contain a highly digestible form of cellulose. The particle size of the soybean hulls prevents undigested material from escaping through the pores of the bag. The soybean hulls remaining in the dacron bag after digestion in the rumen were removed by washing into a centrifuge tube. The resit due remaining after removal of excess water was subjected to cellulose analysis.

Samples of rumen fluid obtained for ammonia-nitrogen, VFA and PEG analysis were strained through four layers of cheesecloth and mixed with mercuric chloride $\left(\mathrm{HgCl}_{2}\right)$. Volatile fatty acid analysis was completed by the procedure of Erwin et al. (1961) with a Bendix Series 2,500 Gas Chromatograph. ${ }^{1}$ Column length was $183.0 \mathrm{~cm}$ with an

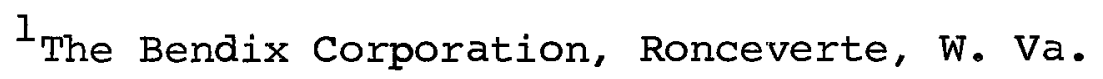


inside diameter of $2 \mathrm{~mm}$. The column packing material used was $10 \%$ SP 1,200 on Chromsorb $W$, acid washed, 80/100 mesh. ${ }^{2}$ Nitrogen, carrier gas, flow was maintained at $60 \mathrm{cc} / \mathrm{min}$. and hydrogen flow at $40 \mathrm{cc} / \mathrm{min}$. Air flow was regulated to a flow rate of $1.6 \mathrm{cc} / \mathrm{min}$. Column temperature was maintained at $120^{\circ} \mathrm{C}$. Calculation of VFA data was by the rectangular method suggested by Carroll (1961). Rumen ammonia nitrogen was measured by procedures recommended for the oxford ${ }^{3}$ ammonia-nitrogen analysis. Polyethylene glycol (PEG) analysis was conducted according to the Hyden procedures as modified by Davis ${ }^{4}$ for polyethylene glycol determination in rumen liquor samples.

Statistical Analysis

All statistical analyses were made by a computer system entitled "Statistical Analysis System" developed by Anthony J. Barr and James Howard Goodnight of the Department of Statistics, North Carolina State University, Raleigh, North Carolina.

The analysis of variance suboption was used to test for differences in response due to ration treatments. Differences between individual rations were tested by the

${ }^{2}$ Supelco, Inc., Bellefonte, Pa.

${ }^{3}$ Oxford Laboratories, San Mateo, Calif.

${ }^{4}$ C.I. Davis, University of Illinois, personal communication. 
use of the least significant difference test. (steel and Torrie, 1960)

Growth and feed efficiency parameters used in trials 1 and 3 were analyzed as a randomized block design. The digestion studies in trials 1 and 3 were analyzed as a split split plot with rations as main plots and weight groups and periods within the trial as subplots. Trials 2 and 4 were analyzed as a split plot with rations as main plots and periods as subplots. The fifth trial was a split plot with the main plot a latin square and days within each cell of the latin square the subplot. 
CHAPTER IV

\section{RESULTS AND DISCUSSION}

\section{Trial 1}

The performance of the lambs in the growth study with low acid hydrolyzed wood residue (LA-HWR) is shown in Table IV and Figures 1,2 and 3 . Sources of variation and degrees of freedom associated with the analysis of variance are given in Appendix Table XV. The lambs consuming $25 \%$ LA-HWR with supplemlental soybean meal (SBM) gained significantly faster $(P<.05)$ than lambs consuming all other rations except the basal alfalfa ration. Weight gain was decreased, in relation to the basal ration, when LA-HWR comprised greater than $25 \%$ of the ration fed. This decrease in weight gain was significant $(P<.05)$ when LA-HWR was incorporated into the ration in amounts greater than $50 \%$, with or without SBM supplementation.

Lambs fed the rations containing LA-HWR consumed more dry matter daily than those fed the basal ration, but these differences were not significantly different $(P<.05)$. The highest average daily dry matter intake was $1.81 \mathrm{~kg}$ for lambs censuming 25\% IA-HWR with SBM, and the lowest was $1.42 \mathrm{~kg}$ for the basal ration. 


\section{TABLE IV}

THE EFFECT ON GROWTH AND FEED EFFICIENCY OF ADDING LOW ACID

- HYDROLYZED WOOD RESIDUE TO LAMB RATIONS, WITH AND

\section{WITHOUT SOYBEAN MEAL SUPPLEMENTATION}

\begin{tabular}{|c|c|c|c|c|c|c|c|}
\hline \multirow{2}{*}{ Item } & \multicolumn{6}{|c|}{ Ration ${ }^{2}$} & \multirow[t]{2}{*}{ S.E. 1} \\
\hline & 1 & 2 & 3 & 4 & 5 & 6 & \\
\hline Weight gain, kg & $18.8^{\mathrm{ab}}$ & $20.3^{a}$ & $16.5^{b c}$ & $15.1^{c}$ & $15.7^{b c}$ & $10.3^{\mathrm{d}}$ & 0.99 \\
\hline $\begin{array}{l}\text { Average daily } \\
\text { gain, kg/day }\end{array}$ & $0.20^{\mathrm{ab}}$ & $0.23^{a}$ & $0.19^{b c}$ & $0.17^{c}$ & $0.18^{b c}$ & $0.12^{\mathrm{d}}$ & 0.01 \\
\hline $\begin{array}{l}\text { Dry matter } \\
\text { intake } \mathrm{kg} / \mathrm{kg} \text { gain }\end{array}$ & $6.99^{a}$ & $7.90^{\mathrm{a}}$ & $9.31^{b}$ & $10.37^{b}$ & $9.43^{b}$ & $12.60^{c}$ & 0.16 \\
\hline $\begin{array}{l}\text { Average daily } \\
\text { dry matter } \\
\text { consumption, } \mathrm{kg}\end{array}$ & $1.42^{a}$ & $1.81^{a}$ & $1.72^{a}$ & $1.76^{a}$ & $1.64^{a}$ & $1.45^{\mathrm{a}}$ & 0.11 \\
\hline $\begin{array}{l}\text { Non-wood dry } \\
\text { matter/kg gain, } \\
\mathrm{kg}\end{array}$ & $6.99^{a}$ & $5.93^{a}$ & $4.66^{b}$ & $2.59^{c}$ & $4.72^{b}$ & $3.15^{c}$ & 0.08 \\
\hline
\end{tabular}

${ }^{1}$ Standard error

2 Ration: 1 = basal ration; $2=25 \%$ LA-HWR + SBM; $3=50 \%$ LA-HWR + SBM; $4=75 \%$

LA-HWR + SBM; $5=50 \%$ LA-HWR; $6=75 \%$ LA-HWR

abcd means on the same line with differing superscripts differ significantly ( $P$.05) 


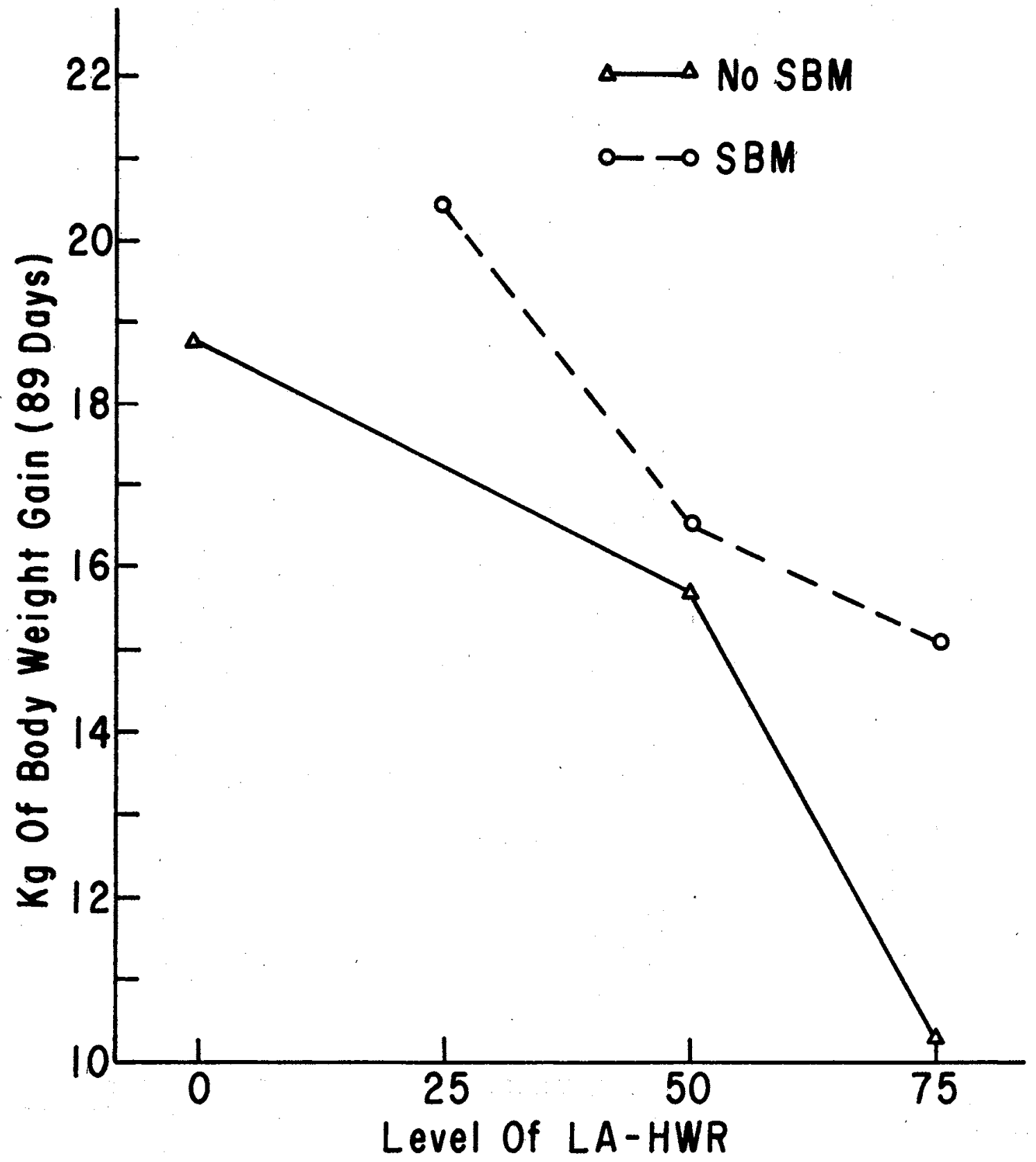

Figure 1. Body Weight Gain of Lambs Consuming LA-HWR With and Without SBM Supplement 


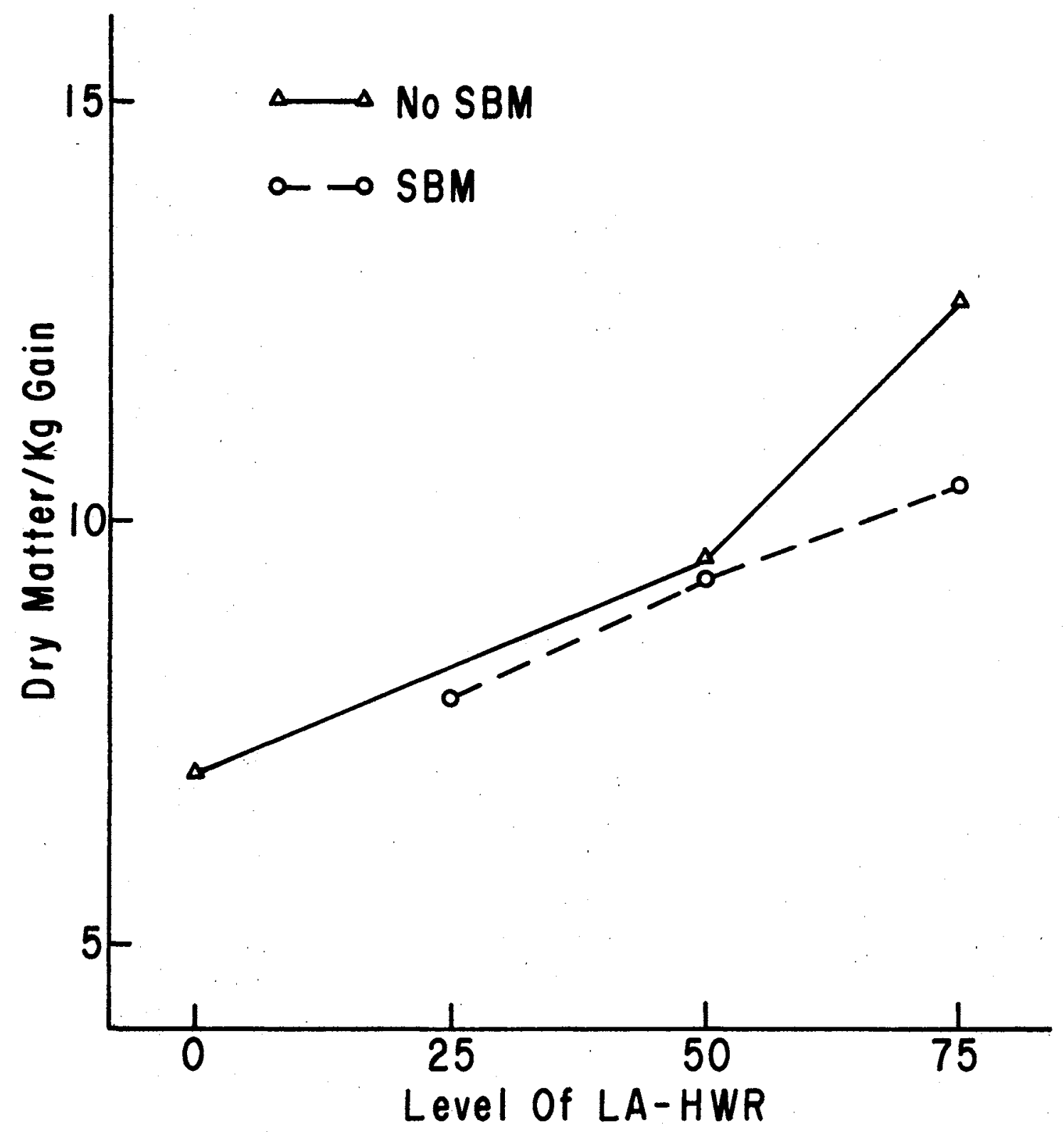

Figure 2. Dry Matter $/ \mathrm{kg}$ of Gain Requirements of Lambs Consuming LA-HWR With and Without SBM Supplement 


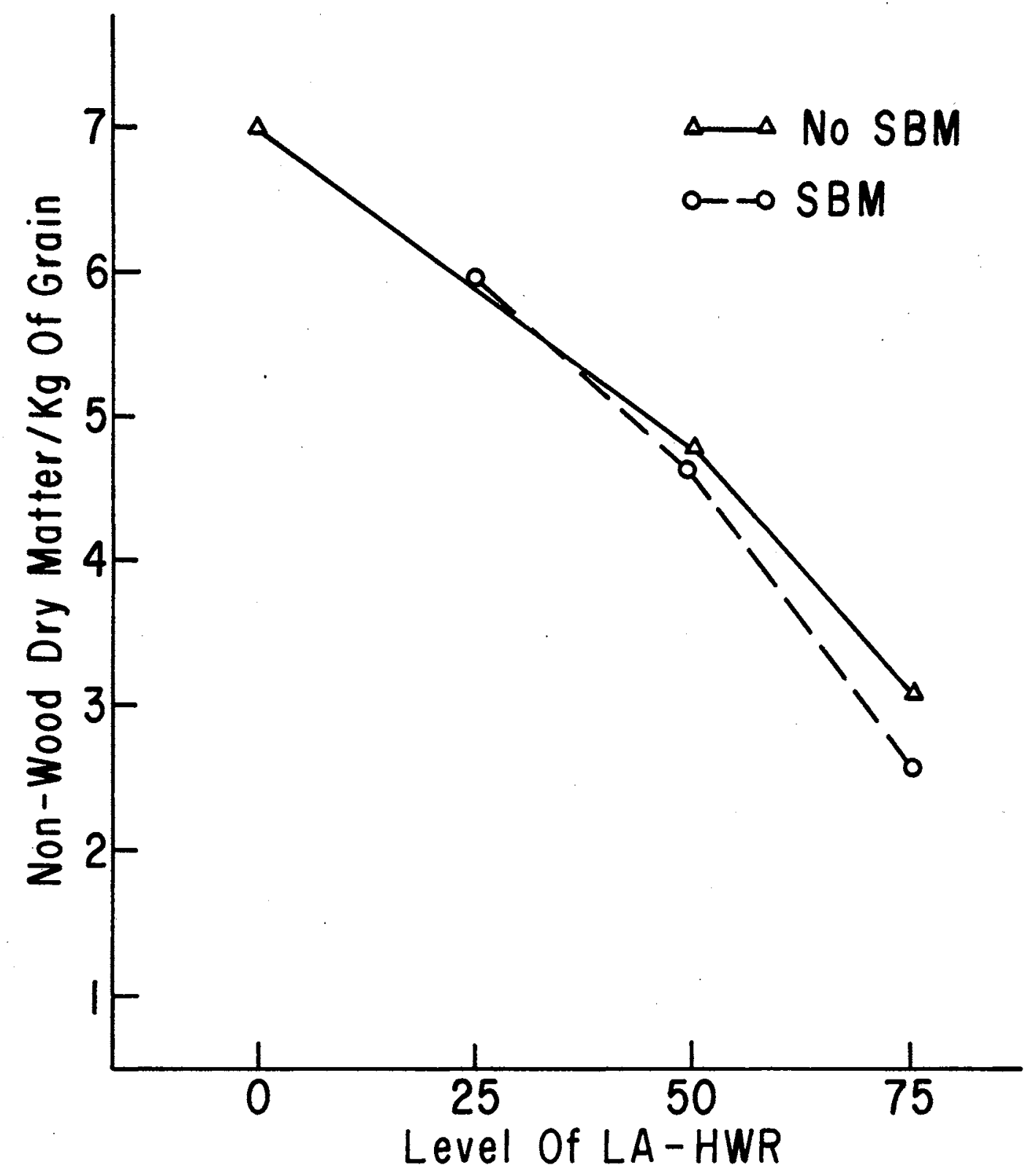

Figure 3. Non-wood Dry Matter $/ \mathrm{kg}$ of Body Weight Gain of Iambs Consuming LA-HWR With and Without SBM Supplement 
Less feed per $\mathrm{kg}$ of gain was required by lambs consuming the basal rations than by lambs consuming rations containing LA-HWR. The differences between lambs fed the basal ration and the lambs fed rations with 50 or $75 \%$ LAHWR were significant $(P<.05)$. Less non-wood dry matter per $\mathrm{kg}$ of gain was needed with increasing amounts of LAHWR, (Figure 1). These data suggest; therefore, that IAHWR was supporting maintenance and gain but with less efficiency than the ration containing only alfalfa meal.

The data from the lambs consuming rations containing 50 and 75\% LA-HWR, with and without SBM, were analyzed using a $2 \times 2$ factorial to determine the effects of SBM supplementation to rations containing LA-HWR. An interaction approaching significance at the $\mathrm{P}<.05$ level, showed: that as the level of LA-HWR increased in the ration the addition of SBM increased body weight gain (Figure 2) and lowered dry matter per $\mathrm{kg}$ of gain requirements, when compared to rations containing the same levels of LA-HWR and no SBM。

Digestion coefficients determined using the rations and lambs in the growth study with LA-HWR are presented in Table $V$. Sources of variation and degrees of freedom associated with the analysis of variance are given in Appendix Table XVI. Periods 1 and 2 of this study refer to the two seven-day fecal collection trials starting on days 14 and 49, respectively. There was a significant period effect in the digestion of dry matter and organic matter. 
TABLE V

DIGESTION COEFFICIENTS OF RATIONS CONTAINING

LOW ACID HYDROLYZED WOOD RESIDUE

\begin{tabular}{|c|c|c|c|c|c|c|c|c|}
\hline \multirow[t]{2}{*}{ Item } & \multirow[t]{2}{*}{ Period $^{3}$} & \multicolumn{6}{|c|}{ Ration $^{2}$} & \multirow[t]{2}{*}{ S.E. ${ }^{1}$} \\
\hline & & 1 & 2 & 3 & 4 & 5 & 6 & \\
\hline $\begin{array}{l}\text { Dry matter } \\
\text { digestibility }\end{array}$ & $\begin{array}{l}1 \\
2 \\
\text { Mean }\end{array}$ & $\begin{array}{l}55.8 \\
59.4 \\
57.6^{a}\end{array}$ & $\begin{array}{l}48.7 \\
53.7 \\
51.2^{b}\end{array}$ & $\begin{array}{l}44.6 \\
45.6 \\
45.1^{c}\end{array}$ & $\begin{array}{l}36.9 \\
40.7 \\
3 \dot{8} .8\end{array}$ & $\begin{array}{l}37.6 \\
40.0 \\
38.0^{d}\end{array}$ & $\begin{array}{l}36.4 \\
37.2 \\
36.8\end{array}$ & 1.6 \\
\hline $\begin{array}{l}\text { Organic matter } \\
\text { digestibility }\end{array}$ & $\begin{array}{c}1 \\
2 \\
\text { Mean }\end{array}$ & $\begin{array}{l}55.0 \\
60.4 \\
57.8^{a}\end{array}$ & $\begin{array}{l}47.4 \\
54.2 \mathrm{~b} \\
50.8\end{array}$ & $\begin{array}{l}44.1 \\
46.0 \\
45.1\end{array}$ & $\begin{array}{l}36.7 \\
40.2 \mathrm{~d} \\
38.4\end{array}$ & $\begin{array}{l}37.2 \\
39.5 \\
38.3\end{array}$ & $\begin{array}{l}35.9 \\
37.0 \\
36.4\end{array}$ & 1.6 \\
\hline $\begin{array}{l}\text { Cellulose } \\
\text { digestibility }\end{array}$ & $\begin{array}{c}1 \\
2 \\
\text { Mean }\end{array}$ & $\begin{array}{l}38.3 \\
36.9 \\
37.6\end{array}$ & $\begin{array}{l}30.1 \\
47.2 \\
38.6\end{array}$ & $\begin{array}{l}30.4 \\
40.7 \\
35.6\end{array}$ & $\begin{array}{l}31.0 \\
48.6 \\
39.8\end{array}$ & $\begin{array}{l}32.4 \\
35.6 \\
34.0\end{array}$ & $\begin{array}{l}36.3 \\
43.4 \\
39.9\end{array}$ & 2.7 \\
\hline $\begin{array}{l}\text { Nitrogen } \\
\text { digestibility }\end{array}$ & $\begin{array}{l}1 \\
2 \\
\text { Mean }\end{array}$ & $\begin{array}{l}57.1 \\
65.4 \\
61.2\end{array}$ & $\begin{array}{l}59.1 \\
59.4 \\
59.3\end{array}$ & $\begin{array}{l}62.9 \\
55.7 \\
59.3\end{array}$ & $\begin{array}{l}62.9 \\
53.8 \\
58.4\end{array}$ & $\begin{array}{l}52.4 \\
50.1 \\
51.3\end{array}$ & $\begin{array}{l}51.5 \\
39.2 \\
45.4\end{array}$ & 1.7 \\
\hline
\end{tabular}

$1_{\text {Standard error }}$

2 Ration: 1 = basal ration; $2=25 \% \mathrm{LA}-\mathrm{HWR}+\mathrm{SBM} ; 3=50 \% \mathrm{LA}-\mathrm{HWR}+\mathrm{SBM} ; 4=75 \%$

LA-HWR + SBM; $5=50 \%$ LA-HWR; $6=75 \%$ LA-HWR

3 Period: Period 1 = days 14-21; Period 2 = days 49-56 of the growth trial

abcd means on the same line with differing superscripts differ significantly $(P<.05)$ 
However, since there was no significant period $\mathrm{x}$ ration interaction, ration effects will be discussed across periods. The dry matter and organic matter digestibilities of the basal ration were significantly higher $(P<.05)$ than the rations containing LA-HWR. The addition of increasing amounts of IA-HWR significantly lowered the dry matter digestibility of the rations with each $25 \%$ increase in LA-HWR (Figure 4). Extrapolation of the regression line calculated from the fegression of the dry matter digestibilities of rations containing 25,50 and $75 \%$ LA-HWR was used to estimate the dry matter digestibility at 100\% LA-HWR in a ration. (The dry matter digestibility of LA-HWR obtained by this procedure was approximately $32 \%$ ). This value is in agreement with the work of Archibald (1926) using Douglas fir with a similar acid hydrolysis. It is important in making this comparison to point out the improvement of wood digestibility by chemical treatment is very species dependent.

There were no statistically significant differences between rations in the digestibility of cellulose. A general trend for all rations containing LA-HWR to improve in cellulose digestibility during the second period suggested that some adaptation of cellulolytic microorganisms have occurred within the rumen. This improvement was not consistant between rations and resulted in significant period and ration $\mathrm{x}$ period effect. The rations showing the most improvement in cellulose digestibility from period 


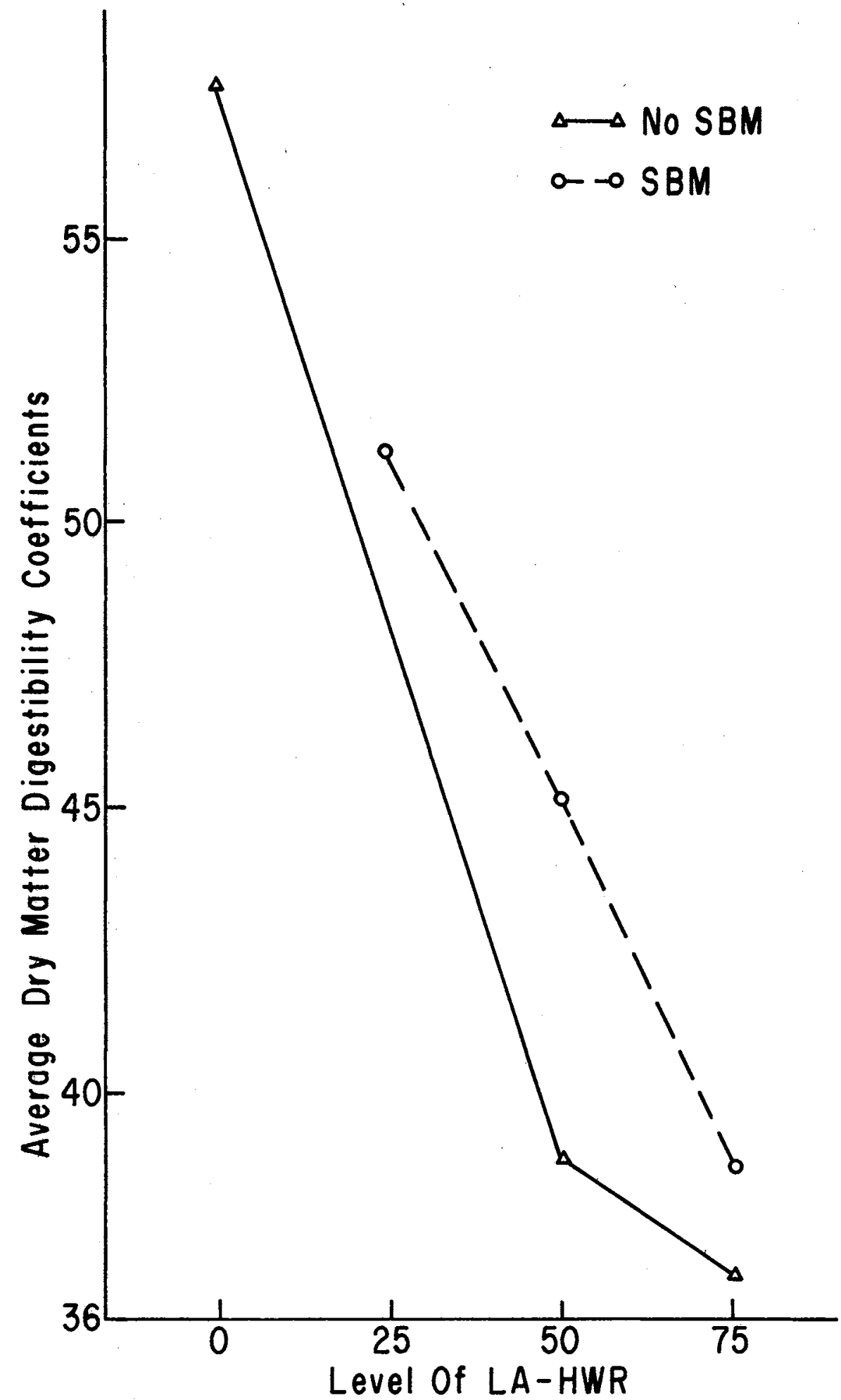

Figure 4. Dry Matter Digestion Coefficients of Rations Containing LA-HWR 
1 to period 2 as a percent of period 1 (Figure 5) were those containing SBM and LA-HWR. Improvements of $57 \%, 34 \%$ and $57 \%$ in cellulose digestion were observed for 25,50 and $75 \%$ LA-HWR, respectively.

Nitrogen digestion coefficients are presented in Table V. Due to significant $(P<.01)$ interactions for weight group $\mathrm{x}$ ration and ration $\mathrm{x}$ period (A.O.V. in Appendix Table XVI), main effects of rations on nitrogen digestibility are difficult to interpret. Percent changes in nitrogen digestibility are presented in Figure 6 . The basal ration showed an increased nitrogen digestibility from period 1 to period 2 ( $14.46 \%$ as a percent of period 1$)$. Rations containing LA-HWR with and without SBM showed marked declines in nitrogen digestibility from period 1 to period 2. Hudson (1971) reported that hydrolyzed pine residue substituted for $15 \%$ of an alfalfa meal diet decreased the crude protein digestibility $5.8 \%$. Supplementation with protein and alkaline materials tended to alleviate'the depression in crude protein digestibility. The results of period 1 indicate that addition of SBM was effective in preventing depression of crude protein digestibility in rations containing LA-HWR. The reason for the decline in nitrogen digestibility in the second period with rations containing 50 and 75\% LA-HWR even with SBM is not apparent. 


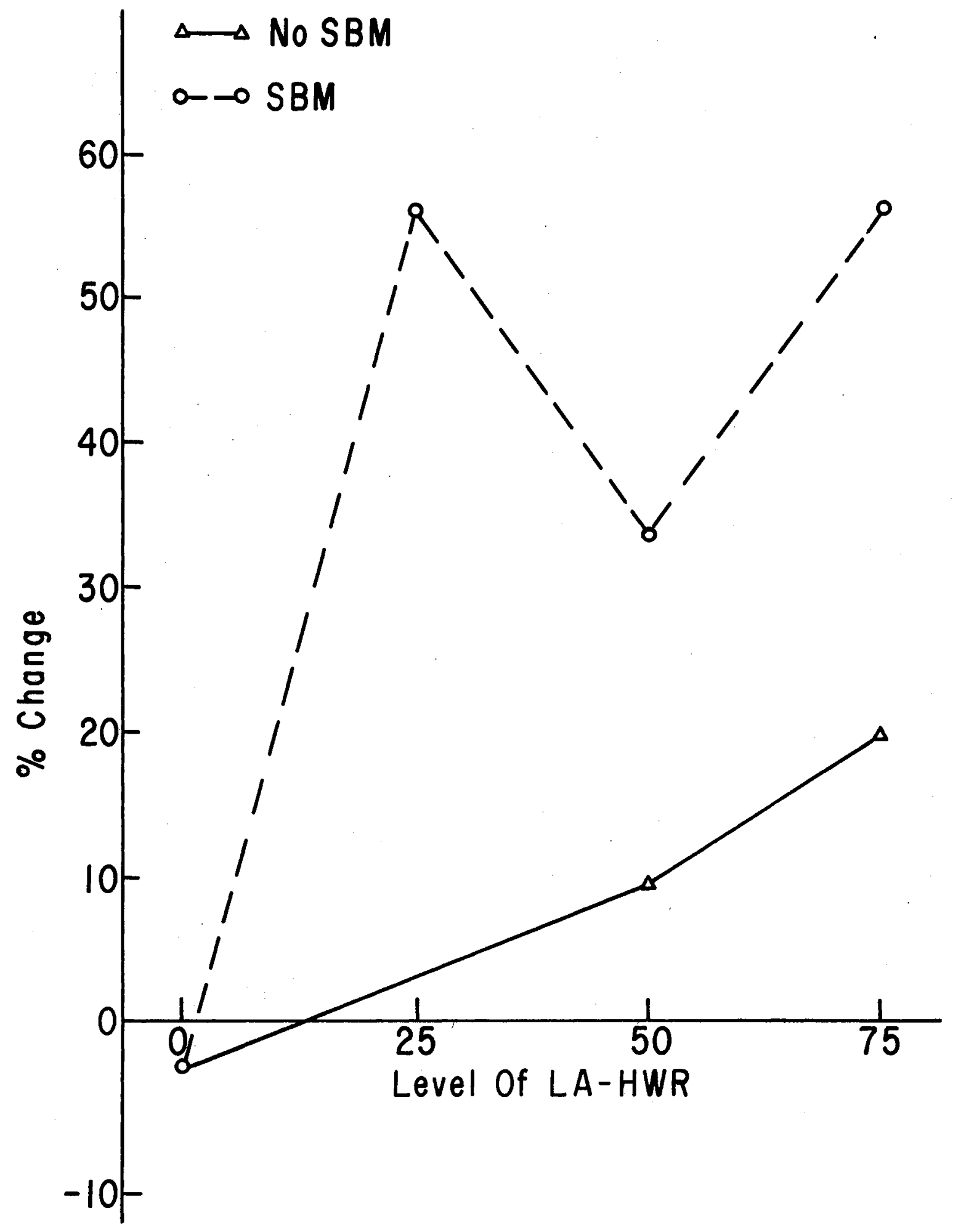

Figure 5. Percent Change in Cellulose Digestibility from Period 1 to Period 2 of Rations Containing LA-HWR 


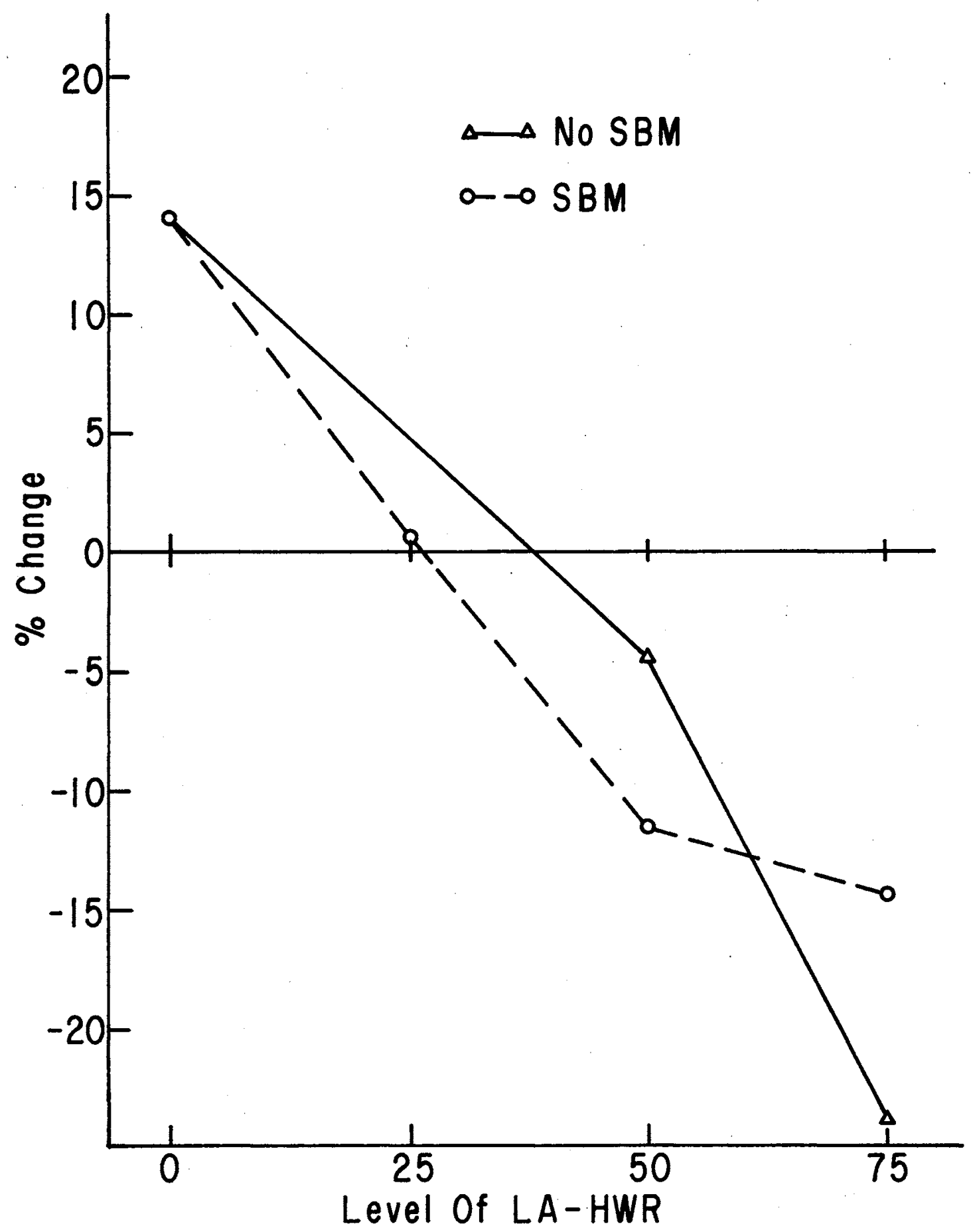

Figure 6. Percent Change in Nitrogen Digestibility from Period 1 to Period 2 of Rations Containing LA-HWR 


\section{Trial 2}

The results of the dacron bag study with the rations containing LA-HWR are presented in Table VI. Periods 1, 2 and 3 correspond to the 4 days following the placement of the dacron bags in the rumen of the lambs on days 14, 35 and 56, respectively. Sources of variation and degrees of freedom for trial 2 are presented in the ppendix Table XVII. The mean digestibilities appeared to be lower for rations containing LA-HWR and SBM when compared with the basal ration. However, there were no statistically significant ration effects on cellulose digestion at the three time intervals the bags were removed from the rumen (15, 30 and 48 hours after being placed in the rumen). Period effects were significant $(P<.05)$ across all times and ration $x$ period effects were significant $(P<.05)$ at 15 hours. There was a large amount of variation in the data as shown by the standard errors.

Attempts at making inferences about ration effects on cellulose digestion at 15 hours were futile because of the large animal variation within rations and the unexplainable differences between periods.

Cellulose digestion at 30 and 48 hours, although not significant, was generally the highest with lambs consuming the basal ration $(73.5$ and $92.2 \%$ at 30 and 48 hours, respectively.

Rations containing 50 and $75 \%$ LA-HWR with SBM 
TABLE VI

DIGESTION OF CELLULOSE IN DACRON BAGS SUSPENDED IN THE RUMEN OF LAMBS CONSUMING RATIONS CONTAINING LOW ACID HYDROLYZED WOOD RESIDUE

\begin{tabular}{|c|c|c|c|c|c|c|c|c|c|}
\hline \multirow[t]{2}{*}{ Time 4} & \multirow{2}{*}{ Period $^{3}$} & \multicolumn{6}{|c|}{ Ration ${ }^{2}$} & \multirow{2}{*}{$\begin{array}{c}\text { Period } \\
\text { Mean }\end{array}$} & \multirow[t]{2}{*}{ S.E. ${ }^{1}$} \\
\hline & & 1 & 2 & 3 & 4 & 5 & 6 & & \\
\hline 15 hours & $\begin{array}{c}1 \\
2 \\
3 \\
\text { Mean }\end{array}$ & $\begin{array}{l}31.9 \\
30.2 \\
42.2 \\
34.8\end{array}$ & $\begin{array}{r}17.9 \\
9.0 \\
43.5 \\
23.5\end{array}$ & $\begin{array}{l}33.9 \\
12.4 \\
44.2 \\
30.2\end{array}$ & $\begin{array}{l}17.1 \\
16.6 \\
18.6 \\
17.4\end{array}$ & $\begin{array}{l}46.3 \\
35.5 \\
29.5 \\
37.1\end{array}$ & $\begin{array}{l}22.0 \\
17.4 \\
39.2 \\
38.6\end{array}$ & $\begin{array}{l}28.2 \\
20.2 \\
36.2\end{array}$ & 13.4 \\
\hline 30 hours & $\begin{array}{c}1 \\
2 \\
3 \\
\text { Mean }\end{array}$ & $\begin{array}{l}85.4 \\
60.3 \\
74.8 \\
73.5\end{array}$ & $\begin{array}{l}64.3 \\
34.7 \\
78.6 \\
59.2\end{array}$ & $\begin{array}{l}64.4 \\
29.0 \\
73.0 \\
55.5\end{array}$ & $\begin{array}{l}45.0 \\
32.2 \\
26.5 \\
34.6\end{array}$ & $\begin{array}{l}71.4 \\
62.7 \\
52.8 \\
62.3\end{array}$ & $\begin{array}{l}48.3 \\
28.8 \\
69.9 \\
49.0\end{array}$ & $\begin{array}{l}63.2 \\
48.2 \\
62.6\end{array}$ & 19.5 \\
\hline 48 hours & $\begin{array}{c}1 \\
2 \\
3 \\
\text { Mean }\end{array}$ & $\begin{array}{l}97.0 \\
86.1 \\
93.5 \\
92.2\end{array}$ & $\begin{array}{l}92.1 \\
81.2 \\
90.2 \\
87.8\end{array}$ & $\begin{array}{l}87.1 \\
55.2 \\
90.2 \\
77.5\end{array}$ & $\begin{array}{l}70.6 \\
60.8 \\
49.9 \\
60.4\end{array}$ & $\begin{array}{l}86.3 \\
93.2 \\
79.6 \\
86.4\end{array}$ & $\begin{array}{l}66.3 \\
52.2 \\
88.9 \\
69.1\end{array}$ & $\begin{array}{l}83.2 \\
71.5 \\
82.1\end{array}$ & 14.8 \\
\hline
\end{tabular}

${ }^{1}$ Standard error

${ }^{2}$ Rations: 1 = basal ration; $2=25 \% \mathrm{LA}-\mathrm{HWR}+\mathrm{SBM} ; 3=50 \% \mathrm{LA}-\mathrm{HWR}+\mathrm{SBM} ; 4=75 \%$ LA-HWR + SBM; $5=50 \%$ LA-HWR; $6=75 \%$ LA-HWR

3 Period: Period 1 - days 14-18; Period 2 - days 35-39; Period 3 - days 56-60 of trial 2

${ }^{4}$ Length of time after being placed in the rumen that dacron bags were removed 
supplement gave consistantly lower cellulose digestion values than similar rations without SBM. A decrease in in vivo cellulose digestion has usually resulted when a source of readily available carbohydrates is added to high fiber rations (Chappel and Fontennot, 1965) and this may partly explain this observation.

Rumen fluid volatile fatty acid concentrations and molar percent data are presented in Table VII. Significant period effects similar to those encountered with the dacron bag study makes the interpretation of these data difficult.

Acetic, butyric and total volatile fatty acid concentrations were significantly higher prior to feeding (0 hour sample) in rumen contents from lambs fed rations 1 and 2 than in contents from lambs fed rations containing 50 and 75\% LA-HWR. There were no significant differences in volatile fatty acid concentration due to rations at sample times of 1,2 and 4 hours post-feeding.

Rumen contents of the lambs fed the basal ration were significantly higher $(P<.05)$ in molar percent acetic and less in molar percent propionic at the zero hour sampling than the rumen contents of lambs fed rations containing 50 and $75 \%$ LA-HWR without SBM.

Trial 3

The results of the growth trial using high acid hydrolyzed wood residue (HA-HWR) are presented in Table VIII 
TABLE VII

RUMEN FLUID VOLATILE FATTY ACIDS FOR TRIAL 2

\begin{tabular}{|c|c|c|c|c|c|c|c|c|}
\hline \multirow{2}{*}{ Ration ${ }^{1}$} & \multirow{2}{*}{ Time ${ }^{2}$} & \multicolumn{2}{|c|}{ Acetic } & \multicolumn{2}{|c|}{ Propionic } & \multicolumn{2}{|c|}{ Butyric } & \multirow[b]{2}{*}{$\begin{array}{l}\text { Total VFA } \\
\text { umoles/ml }\end{array}$} \\
\hline & & $\begin{array}{c}\text { umoles / } \\
\mathrm{ml}\end{array}$ & $\begin{array}{c}\text { mole } \\
\%\end{array}$ & $\begin{array}{c}\text { amoles } \\
\mathrm{ml}\end{array}$ & $\begin{array}{c}\text { mole } \\
\%\end{array}$ & $\begin{array}{c}\text { umoles } \\
\mathrm{ml}\end{array}$ & $\begin{array}{c}\text { mole } \\
\%\end{array}$ & \\
\hline 1 & $\begin{array}{l}0 \\
1 \\
2 \\
4\end{array}$ & $\begin{array}{l}34.9 \\
49.9 \\
67.3 \\
40.9\end{array}$ & $\begin{array}{l}68.7 \\
62.6 \\
70.2 \\
61.1\end{array}$ & $\begin{array}{r}9.2 \\
15.4 \\
20.8 \\
12.7\end{array}$ & $\begin{array}{l}15.47 \\
18.7 \\
21.2 \\
21.3\end{array}$ & $\begin{array}{l}5.0 \\
8.9 \\
7.0 \\
8.0\end{array}$ & $\begin{array}{r}10.7 \\
12.9 \\
7.4 \\
13.8\end{array}$ & $\begin{array}{l}51.4 \\
77.8 \\
96.3 \\
63.3\end{array}$ \\
\hline 2 & $\begin{array}{l}0 \\
1 \\
2 \\
4\end{array}$ & $\begin{array}{l}39.2 \\
60.9 \\
52.7 \\
35.4\end{array}$ & $\begin{array}{l}66.5 \\
71.2 \\
69.5 \\
69.1\end{array}$ & $\begin{array}{l}12.0 \\
17.8 \\
15.7 \\
10.7\end{array}$ & $\begin{array}{l}20.2 \\
20.8 \\
21.2 \\
20.3\end{array}$ & $\begin{array}{l}6.0 \\
6.3 \\
6.6 \\
4.9\end{array}$ & $\begin{array}{r}10.5 \\
7.0 \\
8.5 \\
9.4\end{array}$ & $\begin{array}{l}58.7 \\
85.9 \\
75.7 \\
51.6\end{array}$ \\
\hline 3 & $\begin{array}{l}0 \\
1 \\
2 \\
4\end{array}$ & $\begin{array}{l}23.2 \\
53.7 \\
51.6 \\
42.5\end{array}$ & $\begin{array}{l}64.5 \\
72.0 \\
71.1 \\
69.3\end{array}$ & $\begin{array}{r}9.3 \\
16.4 \\
15.9 \\
13.5\end{array}$ & $\begin{array}{l}25.5 \\
21.8 \\
21.9 \\
23.1\end{array}$ & $\begin{array}{l}2.4 \\
3.9 \\
4.6 \\
4.3\end{array}$ & $\begin{array}{l}6.1 \\
4.8 \\
6.0 \\
6.8\end{array}$ & $\begin{array}{l}36.4 \\
75.1 \\
72.9 \\
60.8\end{array}$ \\
\hline 4 & $\begin{array}{l}0 \\
1 \\
2 \\
4\end{array}$ & $\begin{array}{l}12.0 \\
53.4 \\
38.5 \\
35.0\end{array}$ & $\begin{array}{l}59.1 \\
75.2 \\
70.8 \\
69.1\end{array}$ & $\begin{array}{r}5.9 \\
12.2 \\
11.9 \\
10.3\end{array}$ & $\begin{array}{l}30.7 \\
17.2 \\
20.6 \\
21.8\end{array}$ & $\begin{array}{l}1.3 \\
4.0 \\
3.7 \\
3.8\end{array}$ & $\begin{array}{l}6.1 \\
6.0 \\
6.5 \\
7.5\end{array}$ & $\begin{array}{l}20.0 \\
70.8 \\
55.0 \\
49.8\end{array}$ \\
\hline
\end{tabular}


TABLE VII (Continued)

\begin{tabular}{|c|c|c|c|c|c|c|c|c|}
\hline \multirow{2}{*}{ Ration $^{1}$} & \multirow[b]{2}{*}{ Time $^{2}$} & \multicolumn{2}{|c|}{ Acetic } & \multicolumn{2}{|c|}{ Propionic } & \multicolumn{2}{|c|}{ Butyric } & \multirow[b]{2}{*}{$\begin{array}{l}\text { Total VFA } \\
\text { umoles } / \mathrm{ml}\end{array}$} \\
\hline & & $\begin{array}{c}\text { umoles / } \\
\mathrm{ml}\end{array}$ & $\begin{array}{c}\text { mole } \\
\%\end{array}$ & $\begin{array}{c}\text { umoles/ } \\
\mathrm{ml}\end{array}$ & mole & $\begin{array}{c}\text { umoles/ } \\
\mathrm{ml}\end{array}$ & $\begin{array}{c}\text { mole } \\
\%\end{array}$ & \\
\hline 5 & $\begin{array}{l}0 \\
1 \\
2 \\
4\end{array}$ & $\begin{array}{l}16.4 \\
51.0 \\
39.7 \\
36.1\end{array}$ & $\begin{array}{l}57.5 \\
67.6 \\
64.3 \\
68.6\end{array}$ & $\begin{array}{r}8.7 \\
17.4 \\
14.8 \\
11.9\end{array}$ & $\begin{array}{l}31.5 \\
23.2 \\
23.6 \\
22.7\end{array}$ & $\begin{array}{l}1.6 \\
4.8 \\
5.7 \\
4.0\end{array}$ & $\begin{array}{l}6.2 \\
6.5 \\
9.4 \\
7.5\end{array}$ & $\begin{array}{l}28.1 \\
75.0 \\
61.9 \\
52.7\end{array}$ \\
\hline 6 & $\begin{array}{l}0 \\
1 \\
2 \\
4\end{array}$ & $\begin{array}{l}12.3 \\
57.6 \\
49.4 \\
31.2\end{array}$ & $\begin{array}{l}54.1 \\
75.5 \\
70.8 \\
67.7\end{array}$ & $\begin{array}{r}8.7 \\
15.8 \\
15.2 \\
12.5\end{array}$ & $\begin{array}{l}36.7 \\
19.8 \\
22.6 \\
24.1\end{array}$ & $\begin{array}{l}1.3 \\
2.8 \\
3.7 \\
3.3\end{array}$ & $\begin{array}{l}5.7 \\
3.5 \\
5.3 \\
6.7\end{array}$ & $\begin{array}{l}23.1 \\
77.07 \\
69.2 \\
47.8\end{array}$ \\
\hline
\end{tabular}

$1_{\text {Ration: }} 1$ = basal ration; $2=25 \% \mathrm{LA}-\mathrm{HWR}+\mathrm{SBM} ; 3=50 \% \mathrm{LA}-\mathrm{HWR}+\mathrm{SBM}$;

$4=75 \%$ LA-HWR + SBM; $5=50 \%$ LA-HWR; $6=75 \%$ LA-HWR

2 Hours post feeding that rumen contents samples were taken 
and Figures 7,8 and 9 . Sources of variation and degrees of freedom are presented in Appendix Table XVIII. Lambs consuming the basal ration gained significantly more weight $(\mathrm{P}<.05)$ and consumed less dry matter per $\mathrm{kg}$ of gain than those lambs fed rations containing HA-HWR at 20 and $35 \%$ of the ration either with or without SBM supplement. There were no significant differences in average daily dry matter comsumption at the levels fed in this trial but palatability problems prevented the incorporation of HA-HWR at higher levels than $35 \%$ of the ration.

There were no significant differences in non-wood dry matter per $\mathrm{kg}$ of gain between lambs fed the basal ration and those fed rations containing HA-HWR. The basal ration required 8.17 and $7.50 \mathrm{~kg}$ at 20 and $35 \% \mathrm{HA}-\mathrm{HWR}$ with SBM, respectively. Lambs consuming rations of 20 and $35 \% \mathrm{HA}-\mathrm{HWR}$ without SBM required 8.82 and $7.99 \mathrm{~kg}$ of non-wood dry matter per $\mathrm{kg}$ of gain, respectively. These data suggest that HA-HWR was very poorly utilized as an energy source in the diets of growing lambs. The hydrolysis with $2.3 \% \mathrm{H}_{2} \mathrm{SO}_{4}$ (dry weight of the wood basis) may have resulted in the formation of non-digestible carbohydrate degradation products. Examination of the HA-HWR revealed that the apparent lignin content was increased by hydrolysis from $21 \%$ in the raw wood to $60 \%$ in the HA-HWR. This observation indicates that a large fraction of the HA-HWR was probably indigestible. 
THE EFFECT ON GROWTH AND FEED EFFICIENCY OF ADDING HIGH ACID HYDROLYZED WOOD RESIDUE TO LAMB RATIONS, WITH AND WITHOUT SOYBEAN MEAL SUPPLEMENTATION

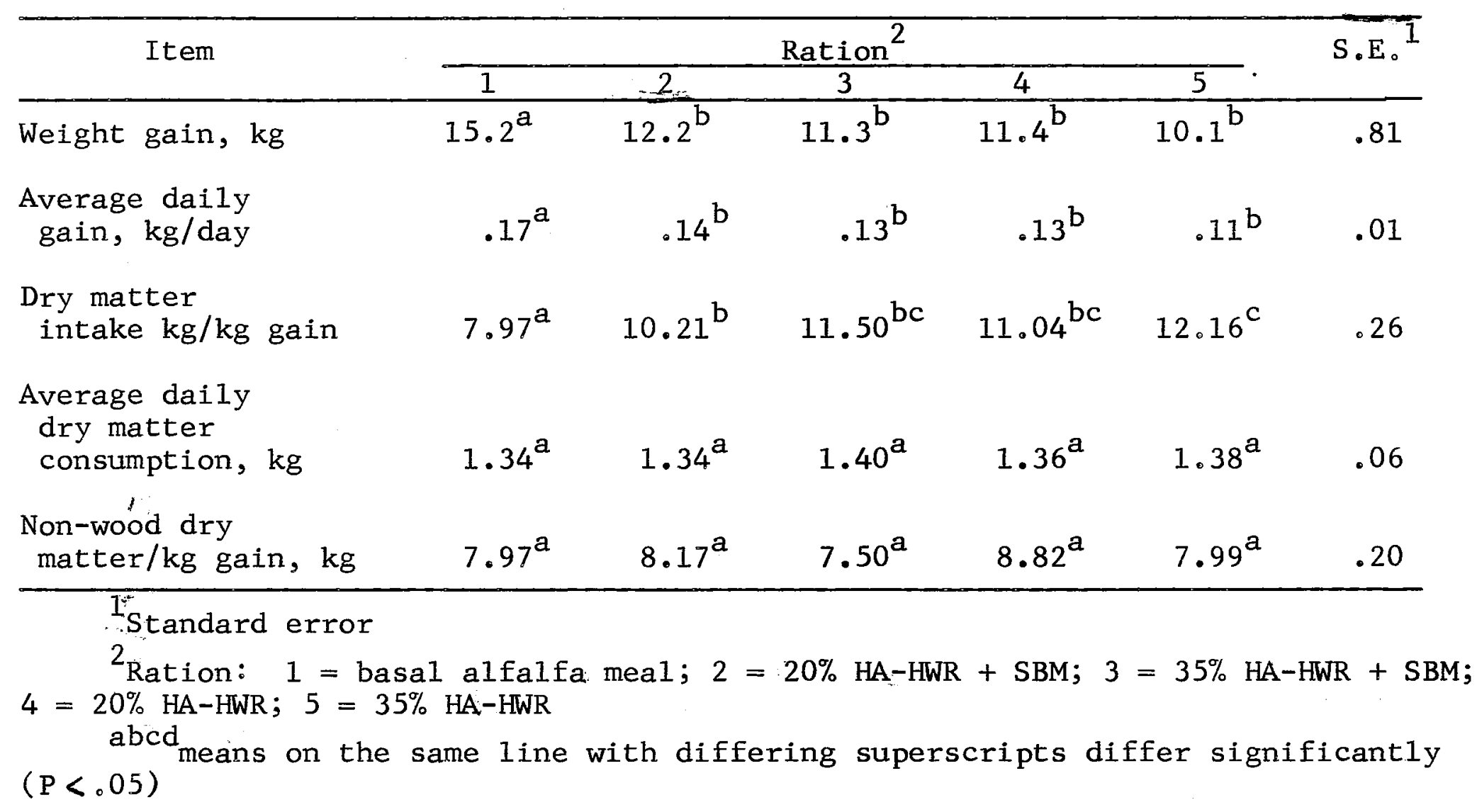




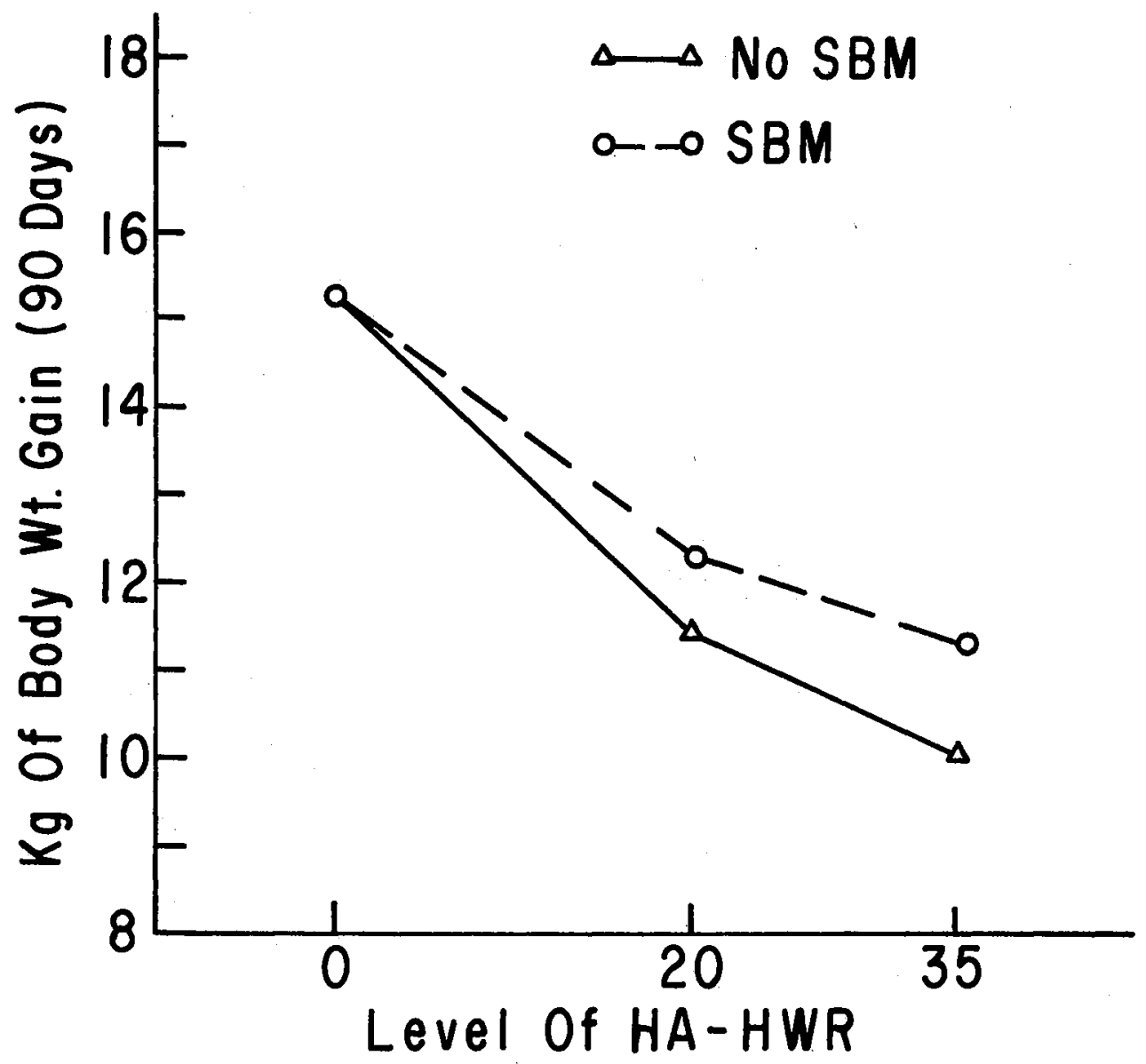

Figure 7. Body Weight Gain of Lambs Consuming HA-HWR With and Without SBM Supplement 


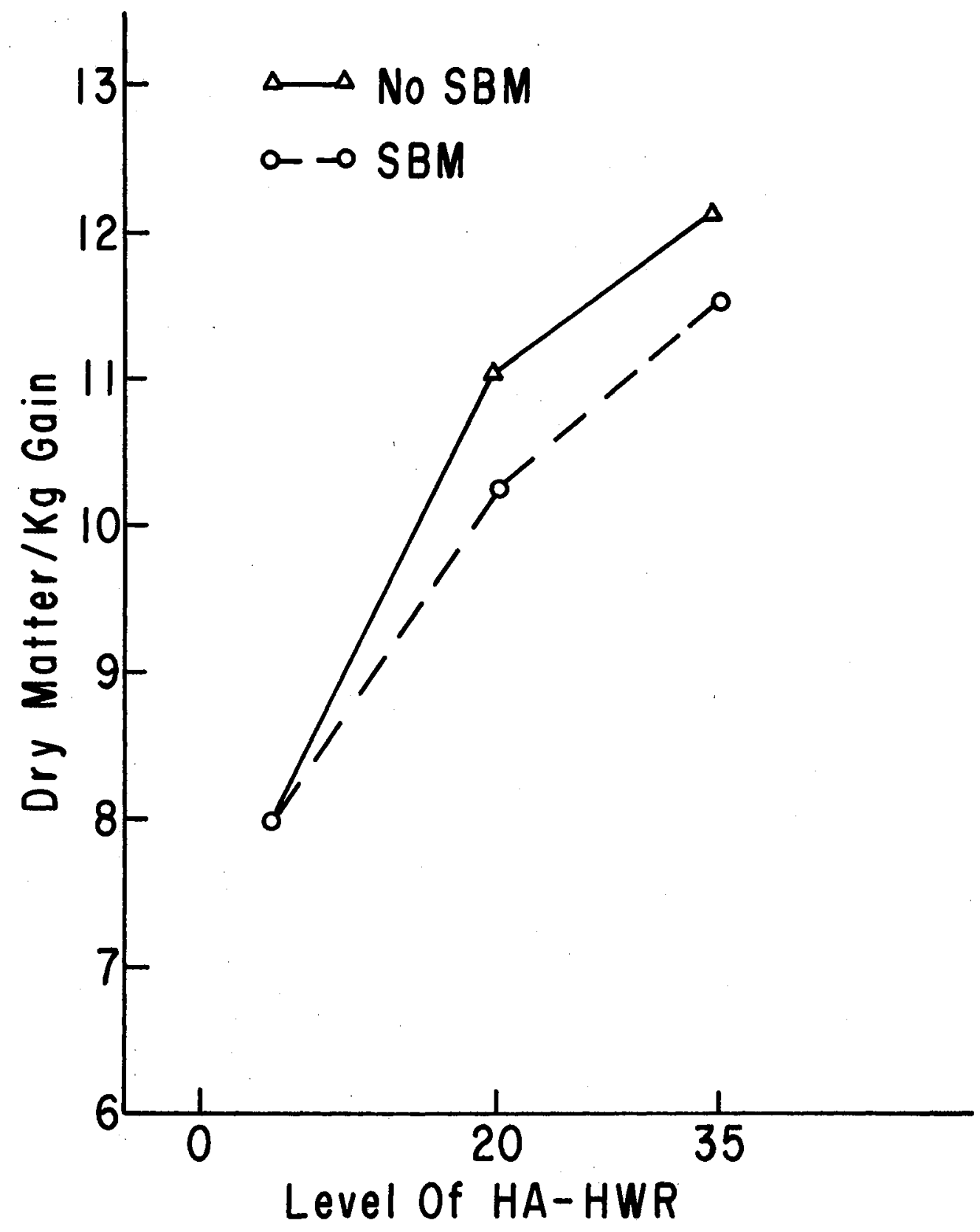

Figure 8. Dry Matter/kg of Gain Requirements of Lambs Consuming HA-HWR With and Without SBM Supplement 


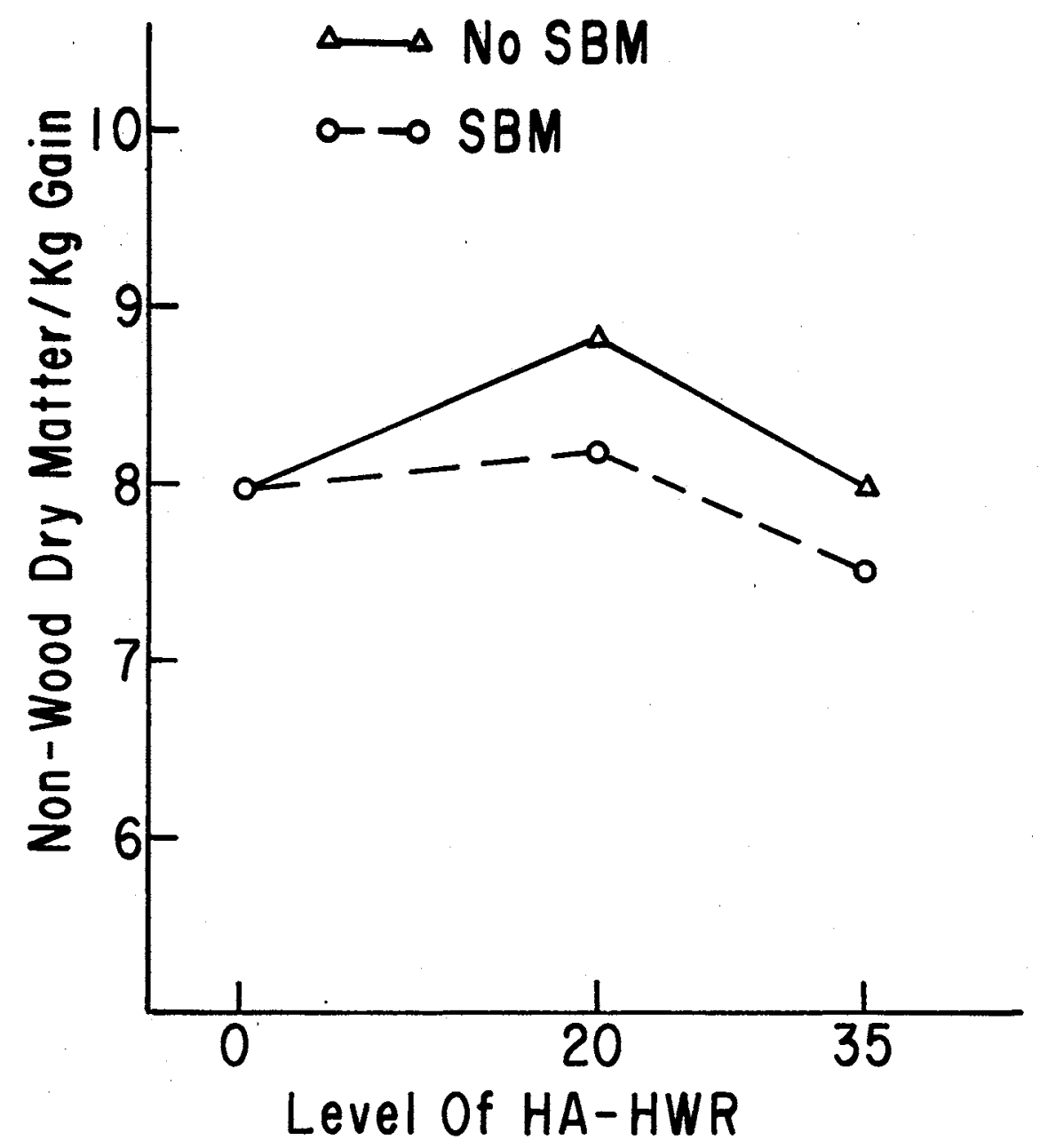

Figure 9. Non-wood Dry Matter/kg of Body Weight Gain of Lambs Consuming HA-HWR With and Without SBM Supplement 
Digestion coefficients fior ary matter, organic matter, cellulose and nitrogen for the rations and lambs used in the growth study with HA-HWR are presented in Table IX. Dry matter and organic digestibilities of rations were decreased when HA-HWR was incorporated into the rations, in comparison to the basal ration. These decreases in digestibility were significant for all rations containing HA-HWR, except when HA-HWR was incorporated into the ration at $20 \%$ with SBM supplement.

Figure 11 presents the change in cellulose digestibilities from period 1 to period 2 as a percent of period 1. Rations containing HA-HWR and SBM showed larger percent increases in the digestibility of cellulose than the basal ration or rations containing HA-HWR and no SBM. Cellulose digestibility was significantly lower for the ration containing 35\% HA-HWR and SBM (ration 3) when compared to all other rations. With the exception of ration 3, no significant difference existed between the other rations, although cellulose digestibility of the rations tended to be decreased by the addition of HA-HWR.

Nitrogen digestibility was significantly depressed by the addition of 20 and 35\% HA-HWR without SBM. Although the actual nitrogen digestion coefficients for the $20 \%$ and $35 \%$ HA-HWR rations with SBM tended to be lower than that of the basal ration, these differences were not statistically significant. 
TABLE IX

DIGESTION COEFFICIENTS OF RATIONS CONTAINING

HIGH ACID HYDROLYZED WOOD RESIDUE

\begin{tabular}{|c|c|c|c|c|c|c|c|c|}
\hline \multirow[t]{2}{*}{ Item } & \multirow[t]{2}{*}{ Period $^{3}$} & \multicolumn{5}{|c|}{ Ration $^{2}$} & \multirow[t]{2}{*}{ Period Mean } & \multirow{2}{*}{ S.E. ${ }^{1}$} \\
\hline & & 1 & 2 & 3 & 4 & 5 & & \\
\hline $\begin{array}{l}\text { Dry matter } \\
\text { digestibility }\end{array}$ & $\begin{array}{c}1 \\
2 \\
\text { Mean }\end{array}$ & $\begin{array}{l}55.2 \\
54.4 \\
54.8^{a}\end{array}$ & $\begin{array}{l}50.3 \\
50.7 \\
50.5^{a b}\end{array}$ & $\begin{array}{l}45.6 \\
45.7 \\
45.7\end{array}$ & $\begin{array}{l}49.8 \\
47.7 \mathrm{bc} \\
48.8^{6}\end{array}$ & $\begin{array}{l}46.2 \\
40.2 \\
43.2\end{array}$ & $\begin{array}{l}49.4 \\
47.7\end{array}$ & 1.69 \\
\hline $\begin{array}{l}\text { Organic matter } \\
\text { digestibility }\end{array}$ & $\begin{array}{c}1 \\
2 \\
\text { Mean }\end{array}$ & $\begin{array}{l}54.3 \\
54.0 \\
54.2^{a}\end{array}$ & $\begin{array}{l}50.0 \\
50.2 \\
50.1^{a b}\end{array}$ & $\begin{array}{l}45.5 \\
44.7 \\
45.1\end{array}$ & $\begin{array}{l}49.9 \\
46.8 \mathrm{bc} \\
48 \cdot 4^{\mathrm{bc}}\end{array}$ & $\begin{array}{l}46.9 \\
39.1 \\
43.0\end{array}$ & $\begin{array}{l}49.3 \\
47.0\end{array}$ & 1.73 \\
\hline $\begin{array}{l}\text { Cellulose } \\
\text { digestibility }\end{array}$ & $\begin{array}{c}1 \\
2 \\
\text { Mean }\end{array}$ & $\begin{array}{l}41.9 \\
42.9 \\
42.4^{a}\end{array}$ & $\begin{array}{l}35.7 \\
43.6 \\
39.7^{a}\end{array}$ & $\begin{array}{l}23.5 \\
35.7 \mathrm{~b} \\
29.6^{b}\end{array}$ & $\begin{array}{l}32.5 \\
45.8 \\
39.2^{a}\end{array}$ & $\begin{array}{l}43 \cdot 7 \\
41 \cdot 1 \\
42 \cdot 2^{a}\end{array}$ & $\begin{array}{l}35.5 \\
41.8\end{array}$ & 1.76 \\
\hline $\begin{array}{l}\text { Nitrogen } \\
\text { digestibility }\end{array}$ & $\begin{array}{c}1 \\
2 \\
\text { Mean }\end{array}$ & $\begin{array}{l}59.6 \\
53.5 \\
56.6^{a}\end{array}$ & $\begin{array}{l}59.4 \\
50.9 \\
55.2^{a}\end{array}$ & $\begin{array}{l}53 \cdot 5 \\
50 \cdot 3 \\
51.9^{a b}\end{array}$ & $\begin{array}{l}52.1 \\
46.8 \mathrm{bc} \\
49.5\end{array}$ & $\begin{array}{l}52.1 \\
39.8 \\
46.0^{c}\end{array}$ & $\begin{array}{l}55.3 \\
48.3 \\
51.8\end{array}$ & 1.73 \\
\hline
\end{tabular}

${ }^{1}$ Standard error

2 Ration: $1=$ basal alfalfa meal; $2=20 \% \mathrm{HA}-\mathrm{HWR}+\mathrm{SBM} ; 3=35 \% \mathrm{HA}-\mathrm{HWR}+\mathrm{SBM}$ :

$4=20 \%$ HA-HWR; $5=35 \%$ HA-HWR

3 Period: Period $1=$ days 14-21; Period 2 = days $49-56$ of the growth trial

with HA-HWR

abcd means on the same line with differing superscripts differ significant1y (PK.05) 


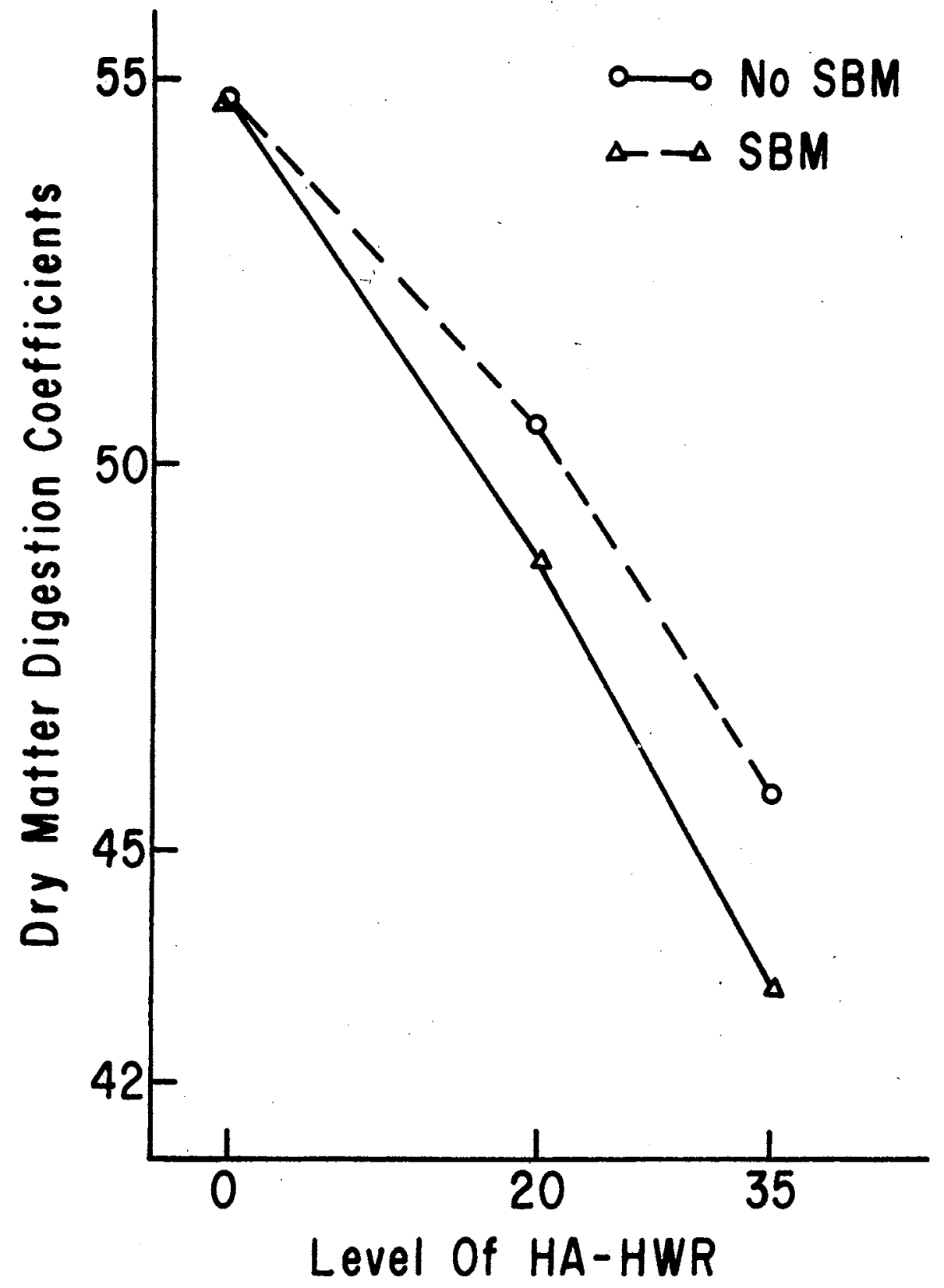

Figure 10. Dry Matter Digestion Coefficients of Rations Containing HA-HWR 
56

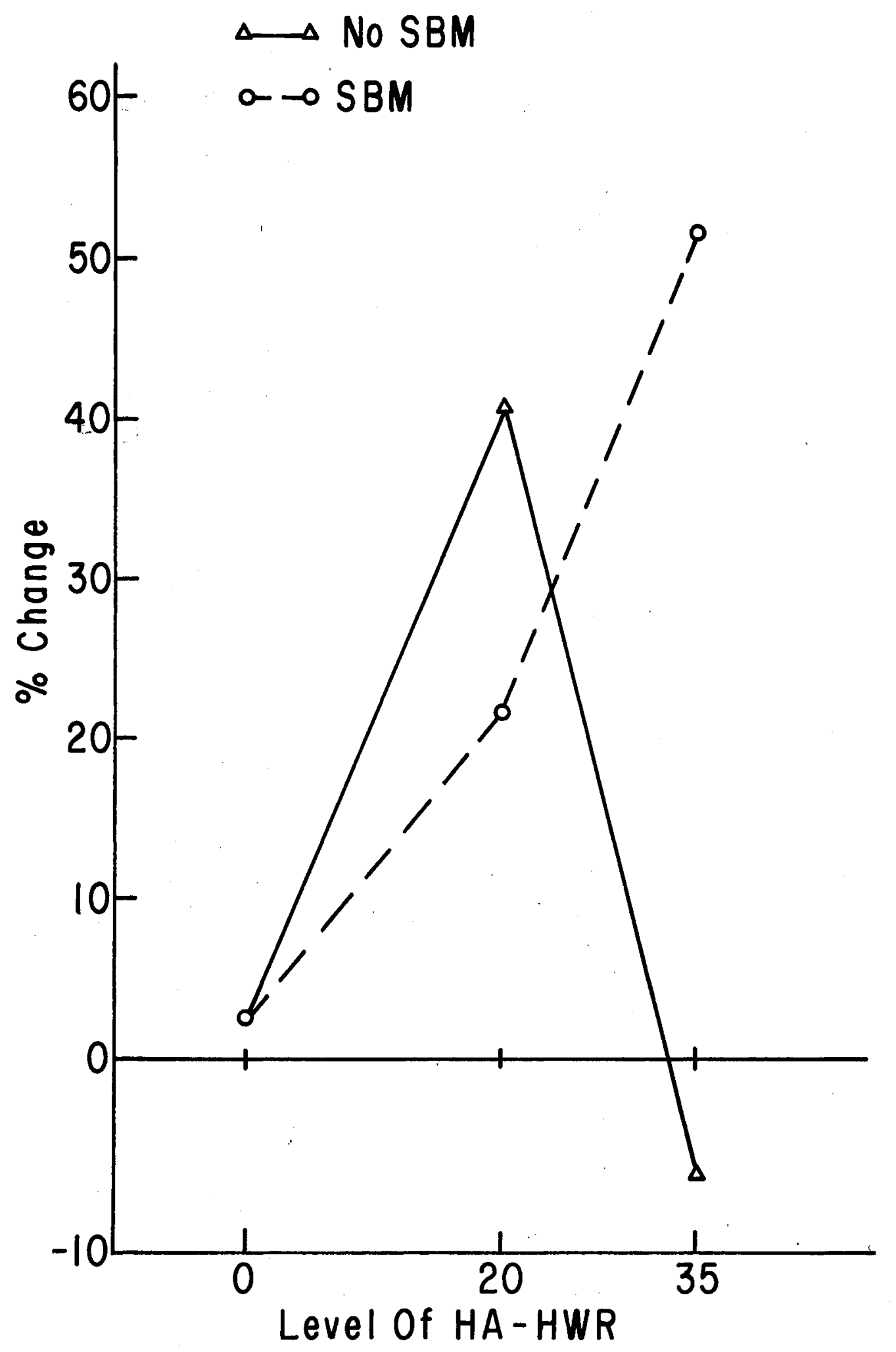

Figure 11. Percent Change in Cellulose Digestbility From Period 1 to Period 2 of Rations containing HA-HWR 
Trial 4

Cellulose digested in dacron bags suspended in the rumen of lambs consuming rations 1,2 and 3 of trial 3 with HA-HWR are presented in Table $x$. Sources of variation and degrees of freedom for the analysis of variance of the data are presented in Appendix Table xx. There were no significant differences in the rate of cellulose digestion as influenced by the dietary regime of the lambs at 15 and 48 hours. Cellulose digested at 30 hours was significantly higher for lambs consuming the basal ration and the ration containing 20\% HA-HWR compared to lambs fed the ration containing 35\% HA-HWR and SBM. These data are in agreement with the results of trial 3 with respect to the depression of cellulose digestibility when $25 \%$ HA-HWR with SBM is fed to lambs. These data suggest that the combination of SBM and HA-HWR have an adverse effect on cellulose digesting microorganisms when they are fed in combination at the level used in this trial. Decreased cellulose utilization may be the result of the utilization of readily available carbohydrates contained in the HA-HWR and the SBM.

Rumen ammonia nitrogen expressed as $\mathrm{\mu g} / \mathrm{ml}$ of rumen fluid at various times after feeding are presented in Table $X I$. Ammonia nitrogen was significantly higher in rumen contents of 1 ambs consuming rations containing HA-HWR than in lambs consuming the basal ration at all sampling times except the 8 hour post-feeding sample. This indicates that 


\section{TABLE X}

DIIGESTION OF CELLULOSE IN DACRON BAGS SUSPENDED IN THE RUMEN OF LAMBS CONSUMING RATIONS CONTAINING HIGH ACID HYDROLYZED WOOD RESIDUE

\begin{tabular}{|c|c|c|c|c|c|c|c|}
\hline \multirow[t]{2}{*}{ Time 4} & & \multirow[t]{2}{*}{ Period $^{3}$} & \multicolumn{3}{|c|}{ Ration $^{2}$} & \multirow{2}{*}{$\begin{array}{c}\text { Period } \\
\text { Mean }\end{array}$} & \multirow[b]{2}{*}{$\mathrm{S}_{\mathrm{E} . \mathrm{E}^{1}}$} \\
\hline & & & 1 & 2 & 3 & & \\
\hline 15 hours & 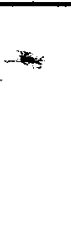 & $\begin{array}{c}1 \\
2 \\
3 \\
\text { Mean }\end{array}$ & $\begin{array}{l}19.7 \\
27.6 \\
24.1 \\
23.8\end{array}$ & $\begin{array}{l}\text { Iose Di } \\
18.6 \\
24.8 \\
40.4 \\
27.9\end{array}$ & $\begin{array}{l}11.8 \\
17.5 \\
27.9 \\
19.0\end{array}$ & $\begin{array}{l}16.7 \\
23.3 \\
30.8\end{array}$ & 7.0 \\
\hline 30 hours & & $\begin{array}{c}1 \\
2 \\
3 \\
\text { Mean }\end{array}$ & $\begin{array}{l}81.2 \\
78.7 \\
71.1 \\
77.0 \mathrm{a}\end{array}$ & $\begin{array}{l}65.4 \\
79.5 \\
97.9 \\
80.9^{a}\end{array}$ & $\begin{array}{l}49.1 \\
54.2 \\
69.1 \\
57.5^{b}\end{array}$ & $\begin{array}{l}65.2 \\
70.8 \\
79.4\end{array}$ & 9.7 \\
\hline 48 hours & & $\begin{array}{c}1 \\
2 \\
3 \\
\text { Mean }\end{array}$ & $\begin{array}{l}95.4 \\
94.8 \\
93.4 \\
94.5\end{array}$ & $\begin{array}{l}90.5 \\
97.4 \\
97.9 \\
95.3\end{array}$ & $\begin{array}{l}78.6 \\
81.9 \\
92.9 \\
84.5\end{array}$ & $\begin{array}{l}88.2 \\
91.4 \\
94.8\end{array}$ & 9.0 \\
\hline
\end{tabular}

\footnotetext{
${ }^{1}$ Standard error

2 Ration: $1=$ basal alfalfa meal; $2=20 \% \mathrm{HA}-\mathrm{HWR}+\mathrm{SBM} ; 3=35 \% \mathrm{HA}-\mathrm{HWR}+\mathrm{SBM}$

3 Period: 1 = Period 1 - days 14-18; Period 2 = days 35-39; Period 3 - days 56-60 of trial 4

${ }^{4}$ Length of time after being placed in the rumen that bags were removed
} 
TABLE XI

RUMEN AMMONIA NITROGEN CONCENTRATION OF LAMBS CONSUMING HA-HWR IN TRIAL 4

\begin{tabular}{|c|c|c|c|}
\hline Time ${ }^{1}$ & $\frac{1}{\mathrm{ug} / \mathrm{mI}}$ & $\begin{array}{c}\text { Ratio } \\
2 \\
\mathrm{ug} / \mathrm{ml}\end{array}$ & $\frac{3}{\mathrm{ug} / \mathrm{mI}}$ \\
\hline 0 & 90.5 & 146.5 & 155.1 \\
\hline 1 & 109.7 & 234.4 & 341.7 \\
\hline 2 & 66.6 & 137.5 & 182.3 \\
\hline 4 & 43.0 & 96.7 & 135.7 \\
\hline 8 & 62.7 & 92.2 & 121.3 \\
\hline
\end{tabular}

$$
\begin{aligned}
I_{\text {Ration: }} \quad \begin{aligned}
1 & =\text { basal alfalfa meal } \\
2 & =20 \% \mathrm{HA}-\mathrm{HWR}+\mathrm{SBM} \\
3 & =35 \% \mathrm{HA}-\mathrm{HWR}+\mathrm{SBM}
\end{aligned} \\
2_{\text {Hours post }} \text { feeding that rumen contents }
\end{aligned}
$$
samples were taken 
at least part of the ammonia used in the neutralization of the HA-HWR during production is rapidly liberated in the rumen shortly after feeding. Results of research with non-protein nitrogen sources indicate that when ammonia concentrations in the rumen fluid exceed a level of 50 $\mathrm{mg} / 100 \mathrm{ml}$, the rate of absorption is so great that the liver cannot completely remove ammonia, the excess of which passes to the general circulation. The toxicity of ammonia involves, as a direct effect of the ammonium ion, a disturbance of the acid base status and changes in the electrolyte balance (Lewis, 1961). Rumen pH samples were not obtained in this trial. Levels of ammonia nitrogen reached $341.6 \mu \mathrm{g} / \mathrm{ml}(34 \mathrm{mg} / 100 \mathrm{ml})$ at 1 hour post-feeding when HAHWR was incorporated into the diet at $35 \%$ of the ration. This level of rumen ammonia although not at the toxic level may have been influential in the alteration of microbial action in the rumen, resulting in lower cellulose digestion and decreased nitrogen utilization in rations containing HA-HWR 。

Rumen volatile fatty acid concentrations for trial 4 are given in Table XII. There were no significant differences in total VFA concentrations; however, the rumen contents of lambs cohsuming the basal ration were consistently higher in volatile fatty acids across all sampling times. 
TABLE XII

RUMEN VOLATILE FATTY ACID CONCENTRATION OF LAMBS CONSUMING HA-HWR

\begin{tabular}{|c|c|c|c|c|c|c|c|c|}
\hline \multirow{2}{*}{ Ration $^{1}$} & \multirow{2}{*}{ Time ${ }^{2}$} & \multicolumn{2}{|c|}{ Acetic } & \multicolumn{2}{|c|}{ Propionic } & \multicolumn{2}{|c|}{ Butyric } & \multirow[b]{2}{*}{$\begin{array}{l}\text { Total VFA } \\
\text { umoles } / \mathrm{ml}\end{array}$} \\
\hline & & $\begin{array}{c}\text { umples / } \\
\mathrm{mi}\end{array}$ & $\begin{array}{c}\text { mole } \\
\%\end{array}$ & $\begin{array}{c}\text { umoles } / \\
\mathrm{ml}\end{array}$ & $\begin{array}{c}\text { mole } \\
\%\end{array}$ & $\begin{array}{c}\text { umoles } \\
\mathrm{ml}\end{array}$ & $\begin{array}{c}\text { mole } \\
\%\end{array}$ & \\
\hline 1 & $\begin{array}{l}0 \\
1 \\
2 \\
4 \\
8\end{array}$ & $\begin{array}{l}21.8 \\
63.6 \\
56.7 \\
45.0 \\
30.5\end{array}$ & $\begin{array}{l}74.4 \\
76.5 \\
74.3 \\
74.4 \\
75.9\end{array}$ & $\begin{array}{r}4.8 \\
13.5 \\
13.4 \\
10.1 \\
6.4\end{array}$ & $\begin{array}{l}15.8 \\
16.5 \\
18.3 \\
17.0 \\
15.0\end{array}$ & $\begin{array}{l}2.1 \\
4.9 \\
4.7 \\
4.6 \\
2.8\end{array}$ & $\begin{array}{l}6.7 \\
5.9 \\
6.4 \\
7.7 \\
6.8\end{array}$ & $\begin{array}{l}29.6 \\
82.8 \\
75.4 \\
60.3 \\
40.5\end{array}$ \\
\hline 2 & $\begin{array}{l}0 \\
1 \\
2 \\
4 \\
8\end{array}$ & $\begin{array}{l}17.9 \\
54.4 \\
45.7 \\
40.1 \\
29.9\end{array}$ & $\begin{array}{l}72.7 \\
75.5 \\
75.2 \\
74.5 \\
75.9\end{array}$ & $\begin{array}{r}12.7 \\
11.2 \\
9.0 \\
7.9 \\
5.5\end{array}$ & $\begin{array}{l}12.7 \\
15.4 \\
15.4 \\
15.1 \\
13.4\end{array}$ & $\begin{array}{l}1.8 \\
4.9 \\
4.4 \\
4.1 \\
3.2\end{array}$ & $\begin{array}{l}7.1 \\
6.6 \\
7.0 \\
7.5 \\
7.1\end{array}$ & $\begin{array}{l}25.0 \\
72.4 \\
60.6 \\
53.6 \\
39.8\end{array}$ \\
\hline 3 & $\begin{array}{l}0 \\
1 \\
2 \\
4 \\
8\end{array}$ & $\begin{array}{l}20.8 \\
57.7 \\
46.2 \\
39.5 \\
27.5\end{array}$ & $\begin{array}{l}70.6 \\
76.0 \\
76.4 \\
74.3 \\
73.3\end{array}$ & $\begin{array}{r}4.8 \\
10.5 \\
7.9 \\
7.3 \\
5.4\end{array}$ & $\begin{array}{l}15.3 \\
14.0 \\
14.0 \\
14.1 \\
15.2\end{array}$ & $\begin{array}{l}2.3 \\
5.6 \\
4.4 \\
4.3 \\
2.8\end{array}$ & $\begin{array}{l}7.7 \\
7.5 \\
7.4 \\
8.3 \\
7.5\end{array}$ & $\begin{array}{l}29.8 \\
75.7 \\
59.6 \\
51.9 \\
36.5\end{array}$ \\
\hline
\end{tabular}

$I_{\text {Ration }}: 1$ = basal alfalfa meal $; 2=20 \% \mathrm{HA}-\mathrm{HWR}+\mathrm{SBM} ; 3=35 \%$ $\mathrm{HA}-\mathrm{HWR}+\mathrm{SBM}$

${ }^{2}$ Hours post feeding that rumen contents samples were taken 
Trial 5

The results of this trial are presented in Tables XIII and XIV. Sources of variation and degrees of freedom for the analysis of variance are presented in Appendix Table XXI. Three steers fed the basal diet and HA-HWR with no added SBM showed irregular response in rumen volume between sampling days within each period of the latin square. Consequently, there were no significant differences in volatile fatty acid concentrations and rumen ammonia data when the parameters were evaluated on total rumen concentrations. The rations were fed on constant dry matter intake basis. Rations containing HA-HWR were poorly consumed and therefore were administered to the steers via the rumen cannula to maintain the desired intake. Total VFA concentrations and rumen ammonia concentrations were higher in the rumen contents of steers consuming $50 \%$ HA-HWR than in the rumen contents of steers consuming the basal ration or the $25 \%$ HA-HWR ration. 
TABLE XIII

TOTAL MOLES OF VOLATILE FATTY ACIDS PRESENT AT 0, 1, 2, 4 AND 8 HOURS POST FEEDING IN THE RUMEN OF STEERS CONSUMING HA-HWR

\begin{tabular}{|c|c|c|c|c|c|c|c|c|}
\hline \multirow[b]{2}{*}{ Ration $^{1}$} & \multirow{2}{*}{ Time ${ }^{2}$} & \multicolumn{2}{|c|}{ Acetic } & \multicolumn{2}{|c|}{ Propionic } & \multicolumn{2}{|c|}{ Butyric } & \multirow{2}{*}{$\begin{array}{c}\text { Total } \\
\text { Moles } \\
\text { VFA }\end{array}$} \\
\hline & & $\begin{array}{l}\text { Total } \\
\text { moles }\end{array}$ & $\begin{array}{c}\text { Mole } \\
\%\end{array}$ & $\begin{array}{l}\text { Total } \\
\text { moles }\end{array}$ & $\begin{array}{c}\text { Mole } \\
\%\end{array}$ & $\begin{array}{l}\text { Total } \\
\text { moles }\end{array}$ & $\begin{array}{c}\text { Mole } \\
\%\end{array}$ & \\
\hline 1 & $\begin{array}{l}0 \\
1 \\
2 \\
4 \\
8\end{array}$ & $\begin{array}{l}1.179 \\
1.980 \\
2.247 \\
2.287 \\
1.875\end{array}$ & $\begin{array}{l}68.9 \\
70.5 \\
69.5 \\
70.4 \\
70.4\end{array}$ & $\begin{array}{l}.332 \\
.588 \\
.704 \\
.681 \\
.534\end{array}$ & $\begin{array}{l}19.4 \\
20.9 \\
21.8 \\
21.0 \\
20.0\end{array}$ & $\begin{array}{l}.113 \\
.165 \\
.197 \\
.212 \\
.194\end{array}$ & $\begin{array}{l}6.6 \\
5.9 \\
6.1 \\
6.5 \\
7.3\end{array}$ & $\begin{array}{l}1.712 \\
2.810 \\
3.232 \\
3.249 \\
2.665\end{array}$ \\
\hline 2 & $\begin{array}{l}0 \\
1 \\
2 \\
4 \\
8\end{array}$ & $\begin{array}{l}1.086 \\
1.667 \\
1.857 \\
1.981 \\
1.482\end{array}$ & $\begin{array}{l}70.8 \\
69.5 \\
67.2 \\
68.5 \\
69.5\end{array}$ & $\begin{array}{r}.279 \\
.479 \\
.589 \\
.588 \\
.403\end{array}$ & $\begin{array}{l}18.2 \\
20.0 \\
21.3 \\
20.3 \\
18.9\end{array}$ & $\begin{array}{l}.103 \\
.179 \\
.231 \\
.243 \\
.171\end{array}$ & $\begin{array}{l}6.7 \\
7.5 \\
8.4 \\
8.4 \\
8.0\end{array}$ & $\begin{array}{l}1.534 \\
2.399 \\
2.764 \\
2.892 \\
2.135\end{array}$ \\
\hline 3 & $\begin{array}{l}0 \\
1 \\
2 \\
4 \\
8\end{array}$ & $\begin{array}{l}1.592 \\
2.952 \\
3.204 \\
3.251 \\
2.894\end{array}$ & $\begin{array}{l}71.6 \\
76.5 \\
73.0 \\
72.8 \\
67.6\end{array}$ & $\begin{array}{r}.369 \\
.532 \\
.677 \\
.587 \\
.698\end{array}$ & $\begin{array}{l}16.6 \\
13.8 \\
15.4 \\
13.1 \\
16.3\end{array}$ & $\begin{array}{r}.169 \\
.265 \\
.371 \\
.465 \\
.507\end{array}$ & $\begin{array}{r}7.6 \\
6.9 \\
8.4 \\
10.4 \\
11.8\end{array}$ & $\begin{array}{l}2.225 \\
3.857 \\
4.392 \\
4.468 \\
4.284\end{array}$ \\
\hline
\end{tabular}

$1_{\text {Ration: }} 1=$ basal alfalfa meal $; 2=25 \% \mathrm{LA}-\mathrm{HWR} ; 3=50 \% \mathrm{HA}-\mathrm{HWR}$

${ }^{2}$ Hours post feeding that rumen samples were taken 
TABLE XIV

GRAMS OF $\mathrm{NH}_{3}$ IN THE RUMEN OF STEERS FED HA-HWR

\begin{tabular}{llll}
\hline Time $^{1}$ & \multicolumn{3}{c}{ Ration } \\
\cline { 2 - 4 } 0 & 4.529 & 3.189 & 3 \\
1 & 4.388 & 6.067 & 5.258 \\
2 & 4.700 & 6.752 & 31.926 \\
4 & 2.187 & 4.563 & 30.735 \\
8 & 2.160 & 2.510 & 27.694 \\
\hline
\end{tabular}

$1_{\text {Ration: }} 1$ = basal alfalfa meal; $2=25 \%$ HA-HWR; $3=50 \%$ HA-HWR

2 Hours post-feeding that rumen contents samples were taken 
General Discussion

The results of trials 1 and 2 with LA-HWR indicate that it would be nutritionally feasible to use large quantities of wood residue in maintenance diets of ruminants. Results of the growth and feed efficiency study with LA-HWR indicate that it may be incorporated into the diet as high as $75 \%$ without palatability problems or toxic effects and still produce body weight gain in lambs. Digestion studies revealed that LA-HWR has a dry matter digestion coefficient of approximately $32 \%$. This is in agreement with the dry matter digestion coefficient obtained by Archibald (1926) for Douglas fir (33\% dry matter digestibility) hydrolyzed with $0.8 \mathrm{H}_{2} \mathrm{SO}_{4}$ with 120 pounds of pressure for 20 minutes. Roughage materials with this degree of dry matter digestibility are comparable to the dry matter digestibility coefficient of many dormant range grasses, which serve as major energy sources in beef cow diets under range conditions. Therefore, it is a matter of economics on the production of LA-HWR as to whether this product can compete as an energy source in ruminant rations.

Examination of the LA-HWR indicated that the cellulose content was decreased from $57 \%$ in the raw wood to $48 \%$ in the LA-HWR, while the lignin content was raised from $21 \%$ in the raw wood to $29 \%$ in the LA-HWR. The increases in lignin content may be attributed to the formation of carbohydrate degradation products. Hardwoods may contain as 
much as $20 \%$ pentosans, which are easily converted to furfural by dilute mineral acids. Hydroxymethlyfurfural may be formed from the degradation of hexoses formed in the hydrolysis of cellulose (Harris, 1952). Other wood constituents such as tannins and resins may be a part of this indigestible artifact lignin.

Hudson (1971) stated that crude protein digestibility was decreased by the incorporation of $15 \%$ pine residue hydrolyzed under similar conditions used in this study with LA-HWR. It was thought that hydroxymethylfurfural (HMF) was responsible for the inhibition of nitrogen utilization. His results indicated that when (HMF) was added to the diet it had no significant effect on crude protein digestibility or animal performance. In further work with hydrolyzed pine residue he found that increasing the crude protein levels and adding alkaline material reduced the detrimental effect on crude protein digestibility. Hudson (1971) hypothesized that the high levels of tannins in wood may be responsible for the depression in crude protein utilization. Hatfield et al. (1969) and Peters et al. (1970) reported using approximately one percent tannins to coat protein to make it partially indigestible in the rumen. The results of the first period of the digestion trials with LA-HWR substantiate the findings about the benefit from adding protein to the hydrolyzed wood residue rations. When SBM was added to LA-HWR rations, nitrogen digestibility was equal to or slightly better than the nitrogen 
digestibility of the basal ration. Reduction of nitrogen digestibility during the second period (after 49 days on feed) may have been due to a build up in the level of tannins in the rumen or in the ration forming complexes with SBM protein and rendering it indigestible.

The results of trials 3,4 and 5 indicate that the utilization of HA-HWR for an energy source in ruminant diets is not feasible. Palatability problems limit the incorporation of high percentages in the diet of ruminants. Trial 3 results showed that there was no significant difference in the amount of non-wood dry matter/ $\mathrm{kg}$ of gain, indicating that the HA-HWR is probably non-digestible material.

Hydrolysis with $2.3 \% \mathrm{H}_{2} \mathrm{SO}_{4}$ reduced the cellulose content from $57 \%$ in the raw wood to $11 \%$ in the HA-EWR. However, the lignin content was raised from $21 \%$ in the raw wood to $60 \%$ in the HA-HWR. Hydrolysis under the conditions used to produce HA-HWR were optimum conditions for the production of furfural. ${ }^{1}$ In addition, it appears that large amounts of hydroxymethylfurfural and other artifact lignin may have been produced, reducing the digestibility and palatibility of high acid hydroldzed wood residue.

$I_{H}$. Dale Turner, Dierks Division, Weyerhaeuser Co., 810 Whittington Ave., Hot Springs, Arkansas. Personal communication. 
It is the author's opinion that varying degreés of acid hydrolysis, between the two methods described in this study, need to be tested and evaluated to determine the optimum point at which digestibility and growth responses are maximum. 


\section{CHAPTER V}

\section{SUMMARY AND CONCLUSIONS}

This study was conducted to evaluate the nutritive value of acid hydrolyzed wood residue (composed of $80 \%$ hardwood and $20 \%$ pine material) in ruminant rations. Two degrees of dilute sulfuric acid hydrolysis were evaluated. Low acid hydrolyzed wood residue (LA-HWR) was produced by treating the wood material with $0.8 \% \mathrm{H}_{2} \mathrm{SO}_{4}$ (dry wood basis) under pressure, High acid hydrolyzed wood residue (HA-HWR) was produced by treatment with $2.3 \% \mathrm{H}_{2} \mathrm{SO}_{4}$ and pressure. After hydrolysis the products were neutralized to a $\mathrm{pH}$ of 6.5 with anhydrous ammonia. The products were mixed in varying proportions with a basal ration of alfalfa meal and fed to lambs in growth and digestion trials. Rations with hydrolyzed wood were tested with and without addition of soybean meal to make them isonitrogenous with the basal alfalfa ration.

No palatability problems were experienced with LA-HWR when incorporated as high as $75 \%$ of an alfalfa meal ration. There were no significant differences in weight gain when lambs fed 25 or 50\% LA-HWR rations were compared to lambs fed the basal ration. Dry matter/kg gain was significantly increased as levels of LA-HWR increased in the diet over 
$25 \%$. Supplementation of $75 \%$ LA-HWR with soybean meal significantly decreased dry matter $/ \mathrm{kg}$ of gain requirements and increased weight gain over rations containing $75 \%$ LA-HWR and no SBM. Digestion studies with LA-HWR indicate it had a dry matter digestibility of $32 \%$. The rate of cellulose digestion in small dacron bags, suspended in the rumen of the test lambs, was not significantly different for any of the ration treatments with LA-HWR. Rumen volatile fatty acid analyses failed to show any significant effect due to the LA-HWR diets. These data suggest that LA-HWR is comparable to a low quality roughage such as weathered range grass and could possibly be used at high levels in maintenance diets for ruminants.

Palatability factors limited the utilization of HA-HWR at more than $35 \%$ of the ration. Growth and digestion studies indicated that HA-HWR was poorly utilized as an energy source in ruminant rations. The incorporation of HA-HWR at the 20 and $3.5 \%$ levels significantly reduced weight gain compared to the basal ration. When compared to the basal ration, dry matter digestibility was significantly decreased in all HA-HWR rations except the 20\% HA-HWR with SBM. Cellulose digestion was significantly lower in the ration containing 35\% HA-HWR and SBM. Dacron bag studies revealed that rate of cellulose digestion was significantly depressed at the 30 hour sampling period by the addition of $35 \% \mathrm{HA}-\mathrm{HWR}$ and SBM to a basal ration. No significant differences were noted at 15 or 48 hours. 
Attempts to evaluate the total concentration of volatile fatty acids and ammonia nitrogen in the rumen of steers consuming HA-HWR failed to show any significant differences although ammonia production was markedly higher in the $50 \%$ HA-HWR ration. 


\section{SELECTED BIBLIOGRAPHY}

Anthony, W.B. and J.P. Cunningham, Jr. 1968. Hardwood sawdust in all concentrate rations for cattle. $\mathrm{J}$. Anim. Sci. 27:1159 (Abstr.)

Anthony, W.B., J.P. Cunningham, Jr. and R.R. Harris. 1969. Hardwood sawdust as feed for ruminants. Advances in Chem. Ser. 95:315.

A.O.A.C. 1960. Official methods of analysis. (9th Ed.) Association of Official Agricultural Chemists. Washington, D.C.

Archibald, J.G. 1924. The effect of sodium hydroxide on the composition, digestibility and feeding value of grain hulls and other fibrous material. J. Agr. Res. $27: 245$.

Archibald, J.G. 1926. The composition, digestibility and feeding value of hydrolyzed sawdust. J. Dairy Sci. $9: 257$.

Balch, C.C. and V.W. Johnson. 1950. Factors affecting the utilization of food by dairy cows. Brit. J. Nutr. $4: 389$.

Blackman, E. and C,B. Baily. 1971. Dissolution of silica from dried grass in nylon bags placed in the rumen of a cow. Can. J.Anim. Sci. 51(2):327.

Boren, F.W., H.B. Pfost, E.F. Smith and D. Richardson. 1965. Cane molasses and hemicellulose extract (wood molasses) in rations for finishing steers. Kansas Expt. Sta. Bull. B483.

Carrol1, K.K. 1961. Quantitative estimation of peak area in gas-liquid chromatography. Nature. 191:377.

Chandra S. and M.G. Jackson. 1971. A study of various chemical treatments to remove lignin from coarse roughages and increase their digestibility. J.Agri. sci. (Camb.) 77:11. 
Chappel, G.I. and J.P. Fontenot. 1968. Effect of level of readily-available carbohydrates in purified sheep rations on cellulose digestibility and nitrogen utilization. J. Anim. Sci. 27:1709.

Cody, R.E., Jr., J.L. Morrill and C.M. Hibbs. 1968. Evaluation of health and performance of bovines fed fiber as a roughage source or intake regulator. J. Dairy Sci. 51:952. (Abstr.)

Crampton, E.W. and L.A. Maynard. 1938. The relation of cellulose and lignin to the nutrient value of animal feeds. J. Nutr. 15:383.

Daniels, L.B., M.E. Muhrer, J.R. Campbell and F.A. Martz. 1971. Feeding heated urea-cellulose preparations to ruminants. J. Anim. Sci. 32(2):342-353.

Dehority, B.A. and R.R. Johnson. 1964. Estimation of the digestibility and nutritive value of forages by cellulose and dry matter solubility methods. J. Anim. Sci. 23:203.

dePadila, F.H. and F.H. Haskins. 1968. Hydrolytic conversion of sawdust into metabolizable sugars. J. Agr. Food Chem. 16:735。

Dinius, D.A., A.D. Peterson, T.A. Long and B.R. Baumgardt. 1970. Intake and digestibility by sheep of rations containing various roughage substitutes. J. Anim. sci. 30:309.

Dinius, D.A. and B.R. Baumgardt. 1970. Regulation of food intake in ruminants. 6. Influence of caloric density of pelleted rations. J. Dairy Sci. 53:311.

Enzmann, J.W., R.D. Goodrich and J.C. Meiske. 1969. Chemical composition and nutritive value of poplar bark. J. Anim. Sci. 29:653.

El-Sabban, F.F., T.A. Long and B.R. Baumgardt. 1971. Utilization of oak sawdust as a roughage substitute in beef cattle finishing rations. J.Anim. Sci. $32: 749$.

el-Shazly, K., B.A. Dehority and R.R. Johnson. 1961. Effect of starch on the digestion of cellulose in vitro and in vivo by rumen microorganisms. J. Anim. sci. 20:268.

Erwin, E.S. and N.G. Elliston. 1959. Rapid method of determining digestibility of concentrates and roughages in cattle. J.Anim. Sci. 18:1518 (Abstr.) 
Erwin, E.S., G.J. Marci and E.M. Emery. 1961. Volatile fatty acid analysis of blood and rumen fluid by gas chromatography. J. Dairy Sci. 44:1768.

Feist, W.C., A.J. Baker and H. Tarkow. 1970. Alkali requirements for improving digestibility of hardwoods by rumen microorganisms. J. Anim. Sci. 30:832.

Gorrill, A.D.I. 1970. Addition of sawdust or shavings to milk replacers for calves. Can. J. Anim. Sci. $50: 385$.

Guggolz, J., R.M. Saunders, T. Klopfenstein and G.O. Kohler. 1971. Enzymatic evaluation of processes for improving agricultural waste ruminant feeds. J. Anim. Sci. 33: 167 .

Guggolz, J., G.O. Kohler and T.J. Klopfenstein. 1971. Composition and improvement of grass straw for ruminant nutrition. J. Anim. Sci. 33:151.

Harris, E.E. 1952. Wood hydrolysis. Wood Chemistry (2nd ed.), edited by L.E. Wise and E.C. Jahn. Reinhold Publishing Corporation. New York.

Hatfield, E.E., A. Driedger, W.S. Garrigus, P.E. Lamb and B.B. Doane. 1969. Effects of treating soybean meal with tannins (R-86). 1969 Beef Day Report. University of Illinois.

Holtzer, W.F. 1952. Alkaline delignification of wood. Wood Chemistry (2nd Ed.), edited by L.E. Wise and E.C. Jahn. Reinhold Publishing Corporation. New York.

Hoflund. S., J.I. Quin and R. Clark. 1948. Studies on the alimentary tract of merino sheep in South Africa. XV - The influence of different factors on the rate of cellulose digestion (a) in the rumen and (b) in ruminal ingesta as studied in vitro. Onderstepoort $\mathrm{J}$. Vet. Sci. and Anim. Ind. 23:395.

Hopson, J.D., R.R. Johnson and B.A Dehority. 1963. Evaluation of the dacron bag technique as a method for measuring cellulose digestibility and rate of forage digestion. J. Anim. Sci. 22:448.

Hudson, J.M. 1971. Factors affecting hydrolyzed sawdust as a feed for animals. Ph.D. Thesis. University of Nebraska. Iincoln, Nebraska.

Johnson, R.R. 1966. Techniques and procedures for in vitro and in vivo rumen studies. J.Anim. Sci. 28:855. 
Jones, J.R. 1949. Wood sugar molasses for dairy cattle. Oregon State Agr. Expt. Sta. Cir. 181.

Kinsman, D.M., D.A. Grant, A.R. Cobb and I.A. Peterson. 1969. Growth and carcass performance of sawdustfed lambs. J. Anim. Sci. 28:875. (Abstr.)

Kitts, W.D., C.R. Kristhnamurti, J.A. Shel ford and J.G. Huffman. 1969. Use of wood and woody by-products as a source of energy in beef cattle rations. Advances in Chem. Ser。 95:279。

Klopfenstein, T.J., R.R. Bartling and W.R. Woods. 1967. Treatments for increasing roughage digestion. J. Anim. Sci. 26:1492. (Abstr.)

Lambert, M.R. and N.I. Jacobson. 1958. The effect of chlortetracycline feeding on cellulose digestion in the bovine rumen. JoAnim. Sci. 17:656.

Lewis, D. 1961. Digestive physiology and nutrition of the ruminant. Butterworths and Co. (Publishers) Itd. London.

Locke, E.G. and Garmun, E. 1961. FAO technical panel on wood chemistry: working party on wood hydrolysis. For. Prod. J。 11:380。

Lusk, J.W., C.B. Browning and J.T. Miles. 1962. Small sample in vivo cellulose digestion procedure for forage evaluation. J. Anim. Sci. 45:69.

Maeng, W.J., D.N. Mowat and W.K. Bilanski. 1971. Digestibility of sodium hydroxide treated straw fed alone or in combination with alfalfa silage. Can. J. Anim. Sci. 51:743.

Manta, L. 1969. The influence of certain supplements and gamma irradiation on the utilization of low quality rbughages by ruminants. Ph.D. Thesis. University of New South Wales.

Marion, R.T., C.E. Fisher and E.D. Robinson. 1957. Ground mesquite wood as a roughage in rations for yearling steers. Texas Agr. Expt. Sta. Progress Rep. No. 1972.

McLaren, G.A., D.A. Jett and R.A. Britton. 1968. Acidresistant hemicellulose and urea utilization. J. Anim. Sci. 27:1171. (Abstr.)

Mellenberger, R.W., L.D. Satter, M.A. Millett and A.J. Baker. 1971. Digestion of aspen, alkali-treated aspen and aspen bark by goats. J. Anim. Sci. 32:756. 
Mellenberger, R.W., I.D. Satter, M.A. Millett and A.J. Baker. 1970. An in vitro technique for estimating digestibility of treated and untreated wood. J. Anim. sci. 30:1005.

Millett, M.A., A.J. Baker, W.C. Feist, R.W. Mellenberger and I.D. Satter. 1970. Modifying wood to increase its in vitro digestibility. J. Anim. Sci. 31:781.

Moir, R.J. and I.E. Harris. Ruminal flora studies in the sheep; influence of nitrogen intake upon ruminal function. J. Nutr. $77: 285$.

Neathery, M.W. 1968. Dry matter disappearance of roughages in nylon bags suspended in the rumen. J. Dairy Sci. $52: 74$.

Oh, H.K., W.M. Longhurst and M.B. Jones. 1969. Relation of nitrogen intake to rumen microbial activity and consumption of low quality roughage by sheep. J. Anim. Sci. 28:272.

Peter, A.P., A. Driedger, I.A. Peterson, E.E. Hatfield, D.L. Hixson, and U.S. Garrigus. 1970. Effects of treated soybean meal on feedlot performance of finishing steer calves (R-103). Beef Cattle Day. University of Illinois.

Pettyjohn, J.D., J.M. Leather and R.D. Mochrie. 1964. Similified technique for in vitro comparison of cellulose and dry matter digestibilities of forages. J. Dairy Sci. 47:1102.

Phander, W.H., S.E. Grebing, G. Hajny and W. Tyree. 1969. The value of wood derived products in ruminant nutrition. Advances in Chem. Ser. 95:298.

Quin, J.I., J.C. Van der Wath and S. Mybrugh. 1938. Studies on the alimentary tract of merino sheep in South Africa. IV. Description of Experimental Technique. Onderstepoort $J$. Vet. Sci. and Anim. Ind. $11: 341$.

Satter, L.D., A.J. Baker and M.A. Millet. 1970。 Aspen sawdust as a partial roughage substitute in a highconcentrate dairy ration. J. Dairy Sci. 53:1455.

Saxena, S.K., D.E. Otterby, J.D. Donker and A.1. Good. 1971. Effects of feeding alkali-treated oat straw supplemented with soybean meal or non-protein nitrogen on growth of lambs and on certain blood and rumen liquor parameters. J. Anim. Sci. 33:485. 
Schaadt H., Jr. and R.R. Johnson. 1969. VFA production in the rumen of sheep fed limestone and urea treated corn silages. J. Anim. Sci. 29:839.

Scott, R.W., M.A. Millet and̀ G.J.Hajny. 1969. Wood waste for animal feeding. For. Prod. J. 19:14.

Sherrard, E.C. and G.W. Blanco. 1921. The preparation and analysis of a cattle food consisting of hydrolyzed sawdust. J. Indus, and Engin. Chem. 13:61.

Simha, K.N., F。A. Marty, H.D。Johnson and LeRoy Hahn. 1970. Use of polyethylene glycol in estimating volume and weight of rumen contents and digestion in cattle. J.Anim. Sci. 30:467.

Singh, M. and M.G. Jackson. 1971. The effects of different levels of sodium hydroxide spray treatment of wheat straw on consumption and digestibility by cattle. J.Agr.Sci。(Camb.) 77:5.

Steel, R.G. and J.H. Torrie. 1960. Principles and procedures of statistics. McGraw-Hill Book Co., New York.

Tarkow, H. and W.C. Filest. 1969. A mechanism for improving digestibility of lignincellulose materials with dilute alkali and liquid ammonia. Advances in Chem. Ser. 95:197.

Turner, H.D. 1964. Feed molasses from the masonite process. For. Prod. 14:282.

Van Dyne, G.M. 1962. Micro-methods for nutritive evaluation of range forage. J. Range Manage. 15:303.

Van Keuren, R.W. and W.W. Heineman. 1962. Study of nylon bag technique for in vivo estimation of forage digestibility. J. Anim. Sci. 21:340.

Welton, R.F. and B.R. Baumgardt. 1970. Relative influence of palatability on the consumption by sheep of diets diluted with thirty and fifty percent sawdust. J. Dairy Sci. 53:1771.

Wilson, R.K. and W.J. Pigden. 1964. Effect of sodium hydroxide treatment on the utilization of wheat straw and poplar wood by rumen microorganisms. Can. J. Anim. Sci. 44:122.

Wood, T.M. 1970. Cellulose and Cellulolysis. World Rev. of Nutr. and Dietetics. 12:227. 
APPENDIX 
TABLE XV

SOURCES OF VARIATION AND DEGREES OF FREEDOM ASSOCIATED WITH THE ANALYSIS OF VARIANCE OF GROWTH AND FEED EFFICIENCY PARAMETERS EVALUATED IN TRIAL 1

\begin{tabular}{lc}
\hline Source & $\begin{array}{c}\text { Degrees of } \\
\text { Freedom }\end{array}$ \\
\hline Ration & 5 \\
Weight group & 2 \\
Ration $\mathrm{x}$ weight group & 10 \\
Error A & 16 \\
Corrected total & 33 \\
\hline
\end{tabular}


TABLE XVI

SOURCES OF VARIATION AND DEGREES OF FREEDOM ASSOCIATED WITH THE ANALYSIS OF VARIANCE OF DIGESTIBILITY PARAMETERS EVALUATED IN TRIAI 1

\begin{tabular}{lc}
\hline \multicolumn{1}{c}{ Source } & $\begin{array}{c}\text { Degrees of } \\
\text { Freedom }\end{array}$ \\
\hline Ration & 5 \\
Weight group & 2 \\
Ration x weight group & 10 \\
Error A & 16 \\
Period & 1 \\
Ration x period & 5 \\
Weight group x period & 2 \\
Ration x weight group x period & 10 \\
Error B & 16 \\
Corrected trial & 67 \\
\hline
\end{tabular}


TABLE XVII

SOURCES OF VARIATION AND DEGREES OF FREEDOM ASSOCIATED WITH THE ANALYSIS OF VARIANCE OF DACRON BAG AND VOLATILE FATTY ACID DATA EVALUATED IN TRIAL 2

\begin{tabular}{lc}
\hline \multicolumn{1}{c}{ Source } & $\begin{array}{c}\text { Degrees of } \\
\text { Freedom }\end{array}$ \\
\hline Ration & 5 \\
Error A & 6 \\
Period & 2 \\
Ration x period & 10 \\
Error B & 12 \\
Corrected trial & 35 \\
\hline
\end{tabular}


SOURCES OF VARIATION AND DEGREES OF FREEDOM ASSOCIATED WITH THE ANALYSIS OF VARIANCE OF GROWTH AND FEED EFFICIENCY PARAMETERS EVALUATED IN TRIAL 3

\begin{tabular}{lc}
\hline Source & $\begin{array}{c}\text { Degrees of } \\
\text { Freedom }\end{array}$ \\
\hline Ration & 4 \\
Weight group & 2 \\
Ration x weight group & 8 \\
Error A & 15 \\
Corrected total & 29 \\
\hline
\end{tabular}


TABLE XIX

\begin{tabular}{lc}
$\begin{array}{l}\text { SOURCES OF VARIATION AND DEGRES OF FREEDOM ASSOCIATED } \\
\text { WITH THE ANALYSIS OF DIGFSTIBILITY } \\
\text { PARAMETERS EVALUATED IN TRIAL 3 }\end{array}$ \\
\hline Source & $\begin{array}{c}\text { Degrees Of } \\
\text { Freedom }\end{array}$ \\
\hline Ration & 4 \\
Weight group & 2 \\
Weight group x ration & 8 \\
Error A & 15 \\
Period & 1 \\
Ration x period & 4 \\
Weight group x period & 2 \\
Ration x weight group x period & 8 \\
Error B & 15 \\
Corrected total & 59 \\
\hline
\end{tabular}


TABLE XX

SOURCES OF VARIATION AND DEGREES OF FREEDOM ASSOCIATED WITH THE ANALYSIS OF VARIANCE OF DACRON BAG, RUMEN AMMONIA, AND VOLATILE FATTY ACID DATA EVALUATED IN TRIAL 4

\begin{tabular}{lc}
\hline \multicolumn{1}{c}{ Source } & $\begin{array}{c}\text { Degrees of } \\
\text { Freedom }\end{array}$ \\
\hline Ration & 2 \\
Error & 9 \\
Period & 2 \\
Ration x period & 4 \\
Error B & 18 \\
Corrected total & 35 \\
\hline
\end{tabular}


TABLE XXI

\section{SOURCES OF VARIATION AND DEGREES OF FREEDOM ASSOCIATED WITH THE ANALYSIS OF VARIANCE OF RUMEN AMMONIA AND \\ VOLATILE FATTY ACID DATA EVALUATED IN TRIAL 5}

\begin{tabular}{lc}
\hline \multicolumn{1}{c}{ Source } & $\begin{array}{c}\text { Degrees of } \\
\text { Freedom }\end{array}$ \\
\hline Animal & 2 \\
Period & 2 \\
Ration & 2 \\
Error A & 2 \\
Day & 1 \\
Animal x day & 2 \\
Period x day & 2 \\
Ration x day & 2 \\
Error B & 2 \\
Corrected total & 17 \\
\hline
\end{tabular}




$$
\begin{aligned}
& \text { VITA }^{\gamma} \\
& \text { Jack Wessner Butterbaugh, Jr. } \\
& \text { Candidate for the Degree of } \\
& \text { MASTER OF SCIENCE }
\end{aligned}
$$

Thesis: THE NUTRITIVE VALUE OF ACID HYDROLYZED WOOD RESIDUE IN RUMINANT RATIONS

Major Field: Animal Science

\section{Biographical:}

Personal Data: Born in Shidler, Oklahoma, March 16, 1948 , the son of Jack W. and Margretta

Butterbaugh.

Education: Graduated from Fairfax High School, Fairfax, Oklahoma, in May, 1966; received the Bachelor of science degree from oklahoma state University with a major in Animal science, in May, 1970; completed the requirements for the Master of science degree in July, 1972.

Professional Experience: Raised and worked on a livestock farm in Northern Oklahoma. Research Assistant in the Department of Animal Science, Oklahoma state University, Stillwater, Oklahoma, 1970-72. 